Frances E. Aboud

ETHNIC AND ROLE STEREOTYPES: THEIR RELATIVE IMPORTANCE IN PERSON PERCEPTION

The present study focused on two important factors in person perception, viz., ethnic stereotypes and role stereotypes. These two processes were assessed individually and in combination to determine their relative importance in the perception of a person. In two separate experiments, English Canadian and French Canadian Ss varying in the amount of contact they had with the other ethnic group were asked to rate on a number of adjective and behavior dimensions the two ethnic concepts English Canadian and French Canadian and two role concepts, either Student and Teacher or Male and Female, as well as the ethnic-role combination (e.g., English Canadian Male). Comparisons of the polarized perceptions of these concepts and a multiple regression analysis indicated that role stereotypes are utilized more for rating in-group combinations but ethnic stereotypes are used more for rating out-group combinations. Furthermore, contact with the out-group appeared to increase the use of role stereotypes for out-group perception. The results are discussed in terms of a theory of ethnic group interaction. 
M.A. Thesis

Frances E. Aboud

PSYCHOLOGY

Short Title

ETHNIC AND ROLE STEREOTYPES 


\section{ETHNIC AND ROLE STEREOTYPES: THEIR RELATIVE \\ IMPORTANCE IN PERSON PERCEPTION}

by

Frances E. Aboud

A thesis submitted to the Faculty of Graduate Studies and Research in partial fulfilment of the requirements for the degree of Master of Arts.

Montreal 


\section{ACKNOWLEDGEMENTS}

The research reported in this thesis was supported by a grant (S69-1425) from the Canada Council to Dr. Donald M. Taylor.

The writer is grateful to Dr. Donald M. Taylor for his enthusiastic assistance in carrying out this study and for his critical reading of the manuscript. The writer also wishes to acknowledge Dr. J. O. Ramsay for his advice on statistical and scaling matters, and Lise Simard for helping to collect the data. 
TABLE OF CONTENTS

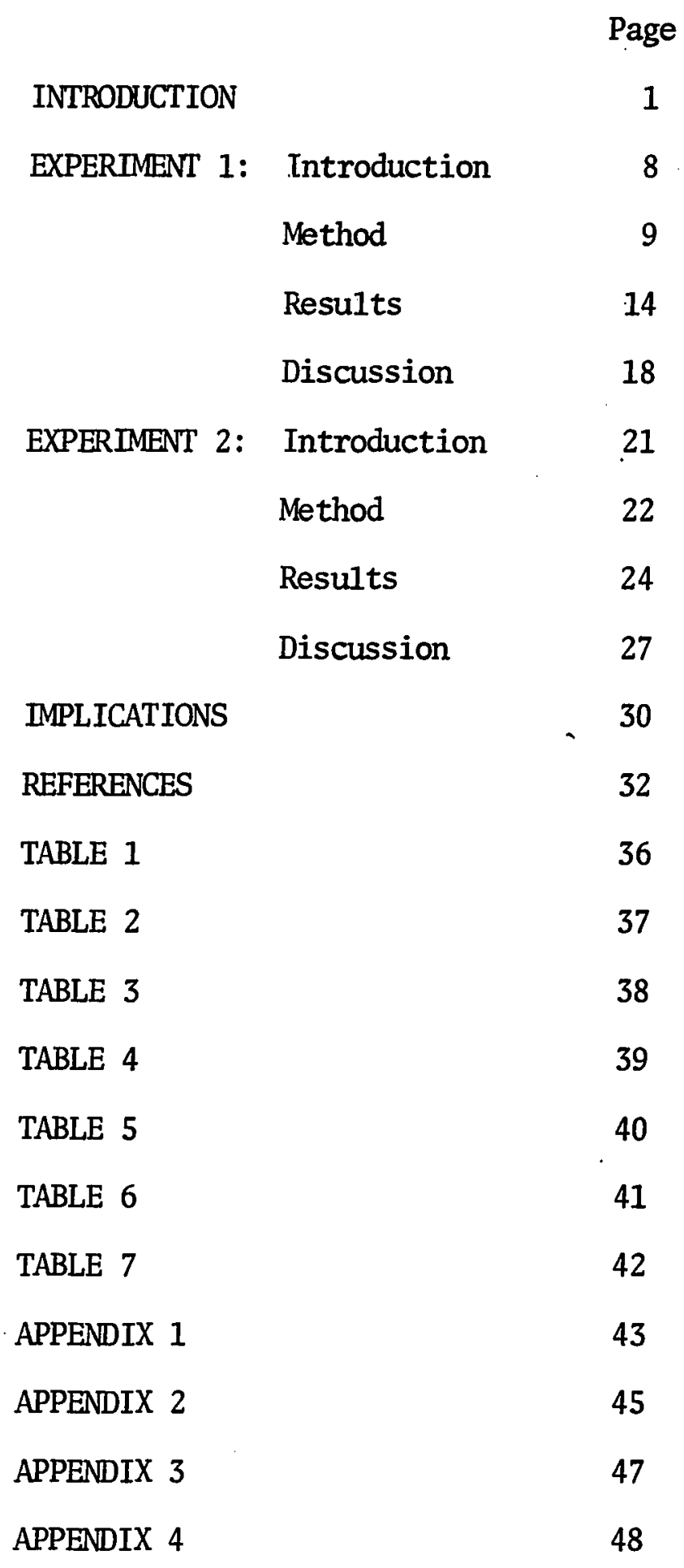




\section{INTRODUCTION}

Social scientists who study person perception are typically concerned with how people form impressions of one another. The ultimate aim of studying person perception is not only to understand impression formation as a process, but also to explain the behavior that results from perception. When one person's perception of another is inaccurate and available cues have been misinterpreted, it is reasonable to expect that subsequent interaction between the two persons will not be smooth or efficient. The purpose of studying ethnic perception, then, is first to understand the cognitive processes involved in this perception and secondly to link it with crosscultural interaction and ethnic relations. In this thesis, an attempt will be made to link ethnic group perception to both the cognitive processes underlying it and the cross-cultural interaction resulting from it.

Tagiuri's (1969) comprehensive assessment of recent research in person perception points to the significance of set and other cognitive processes. He is concerned here with the cognitions which make up the "implicit personality theory"; and describes them as assumptions that we have about people which determine what proximal and distal cues of the stimulus person are processed by the perceiver and how these cues are interpreted. Sarbin, Taft, and Bailey (1960) have pointed out that cues emanating from social stimuli in particular are vague and often ambiguous. The best possible inferences about these stimuli, therefore, require the mediation of cognitive structures to a large extent. Very few studies, however, have actually shown how various cognitive processes utilize and combine available cues to produce an integrated perception.

A number of cognitive processes contributing to the implicit personality theory have been investigated. It has been found that such tendencies 
as assumed similarity, halo effect, logical error, attribution of intentionality, and attribution of personality invariance can influence the formation of impressions. Categorization or stereotyping is also a cognitive process known to influence person perception and is a process of special significance for ethnic perception (Secord, 1958). Stereotypes are usually defined as a relatively persistent set of beliefs, expectancies, or preconceptions about members of a particular group. There are several other characteristics of stereotyping that can be extracted from the many definitions offered by social psychologists since Lippmann (1922) first called them "pictures in the head". As a process they are concerned with categorizing or generalizing about people; stereotypes are socially acquired, mainly through verbal behavior, and consequently display a high degree of social consensus (e.g., Fishman, 1956).

Because of the importance of stereotyping in ethnic perception, this process will be the major focus of the present investigation. Two cognitive structures will be explored and contrasted--ethnic stereotypes and role stereotypes. Both have been found separately to be influential in the process of person perception.

Research on ethnic stereotypes has focused primarily on an assessment of the content of the stereotype. In response to an ethnic label (Katz \& Braly, 1933, 1935; Meenes, 1943; Gilbert, 1951), accented voice (Lambert, Hodgson, Gardner \& Fillenbaum, 1960; Lambert, 1967; Tucker, 1968) or identified picture (Razran, 1950; Secord, Bevan, \& Katz, 1956; Secord, 1959), Ss assigned traits that they felt best described the stimulus. The traits most frequently used to describe the ethnic group or members of the ethnic group were included in the stereotype. Most of these earlier studies, however, have one of two major weaknesses. The first is concerned with a 
failure to demonstrate the operation of stereotypes in person perception. For example, Katz and Braly (1933), Gilbert (1951), and Meenes (1943) specifically asked students to give categorical responses; Ss were provided with only an ethnic label and were therefore forced to generalize. These results cannot be used as evidence for the operation of stereotypes in mediating person perception; they indicate merely that people are able to stereotype. The second deals with a failure to discover the content of the stereotype before studying its use in perception. That is, researchers have measured $\underline{S s}^{\prime}$ ratings of persons who were known to be members of a particular ethnic group and assumed that stereotypes were influencing this perception without actually assessing the stereotype veforehand, and relating it to the final perception. It is essential that experiments of this nature include both an assessment of the stereotype and an indication of its operation in actual perception.

There are three recent experiments which have taken these two factors into account. In general, they indicate that Ss will utilize information steming from the perceived person or the context, but that stereotypes will also play a large part in determining their reactions to the ethnic person. Tajfel, Sheikh, and Gardner (1964) showed that stereotypes were used to reduce the differences perceived between members of the same ethnic group in an informal setting. Two other studies by Gardner and Taylor (1968) and Taylor and Gardner (1969) demonstrated that certain conditions will minimize the functioning of ethnic stereotypes. But only when peer social pressure not to stereotype was combined with an anti-stereotype communication from an ethnic group representative did $\underline{S}$ describe the target person in an antistereotype manner. We can conclude, therefore, that ethnic stereotypes play a significant role in ethnic perception. 
A similar situation exists in the study of role stereotypes. Friedman and Gladden (1964) using the semantic differential of Osgood, Suci, and Tannenbaum (1957) found considerable consensus among Ss' ratings of juvenile delinquent, child, adolescent, and adult. Triandis, Vassiliou, and Nassiakou (1968) assessed the different role perceptions that Americans and Greeks have about family members and others using a role differential scale. This scale measured how appropriate it was in each culture for a person in a particular role to behave in a certain way towards a complementary role; for example, for a husband to show respect for his wife. Sarbin and Rosenberg (1955) used an adjective checklist to assess the self concept held by students, males, females, Roman Catholics, and Protestants. These cognitive expectations have been related to perception indirectly (Jones \& de Charms, 1958) by manipulating the role of the perceiver (and thereby the entire role set including the role of the perceived person) and noting how this affects his perception of a person or a situation. Jones and de Charms (1958) found a difference in the impressions formed about a particular individual depending on which role the subject was told to adopt. Finally, Sarbin, Taft, and Bailey (1960) have extended the application of role concepts to perception and inference in a clinical setting. There is good evidence, then, that role stereotypes influence perception.

To date, these two cognitive structures--role stereotypes and ethnic stereotypes--have been studied separately. In most social interactions, however, the two sets of beliefs will be operating together. For example, when one meets a French Canadian lawyer, there are immediately at least two sets of information upon which to base an impression of him: Beliefs about his ethnic group, and characteristics that one would expect from a person in that role. Little is known, however, about how these two sets relate to one 
another and how they interact during the process of person perception. Although role and ethnic stereotypes have not been explored together in person perception, there are two related lines of research which do suggest that judges will combine isolated pieces of information to form a total impression. Triandis has conducted a number of studies (e.g., Triandis \& Fishbein, 1963; Triandis, Loh, \& Levin, 1966) which examined the cues or factors involved in determining a person's evaluation and behavioral intentions towards another person. In the first study, correlations of .65 were attained between obtained scores and scores predicted from a knowledge of the $\underline{S} s^{\prime}$ evaluations of the attributes (race, occupation, religion, and nationality) making up the complex person-stimulus. In the second study, such attributes as race, status, quality of spoken English, and opinions about civil rights were found to contribute to interpersonal attitudes and behavioral intentions in different patterns.

Other studies in impression formation have tried to quantify the manner in which people combine several pieces of information in the form of trait adjectives to make inferences about a person. Asch (1946) emphasized the concept of a central trait which determined to a large extent the meaning of the other given traits and the inferences based on them. Asch applied the Gestalt notion of the whole being something other than the mere sum of its parts to the process of person perception. Others since then (e.g., Bruner, Shapiro, \& Tagiuri, 1958; Wishner, 1960) have claimed that inferences based on a combination of traits are predictable from inferences based on the component traits in isolation. For example, Bruner, Shapiro, and Tagiuri found that when two traits (or two out of three traits) singly pointed in the same inferential direction, their combination was also rated in that direction. If the two traits in isolation produced conflicting inferences, 
then their combination was rated with the same sign as the stronger component. Others (e.g., Anderson \& Jacobson, 1965; Triandis \& Fishbein, 1963) have specified this relationship more mathematically as a simple or weighted averaging or summation process. The general feeling, then, is that the way in which people do combine several bits of information to form an impression can be studied quantitatively by relating it to impressions based on the bits of information singly.

The present thesis will attempt to formulate a pattern for the interaction of the two cognitive sets--role and ethnic stereotypes--as they influence in-group as compared with out-group perception.

The establishment of a pattern with respect to the interaction of ethnic and role stereotypes in person perception should bear directly on a theory of ethnic group interaction. Though both role and ethnic stereotypes involve a set of expectancies or categorical responses about members of a particular group, there is one very subtle but important difference between the two. This has to do with the extent to which these stereotypes consist of a set of norms and thereby become useful predictors of behavior, leading to efficient interaction. Expectations about a role are generally considered to be normative; one typically finds people conforming to the prescriptions for a particular role. Consequently, our inferences about the way a person in a particular role will act are often accurate, more accurate even than information about that person's personality (Sarbin, Taft, \& Bailey, 1960). On the other hand, expectations about an ethnic group are not generally considered to be prescrintive; they are merely generalizations about an ethnic group (Brown, 1965). These generalizations may be valid to some extent but unless the group holding them is powerful enough to enforce conformity, members of the stereotyped group will not feel obliged to act in accordance with 
the stereotype. Consequently, inferences steming from an ethnic stereotype are not often likely to be an accurate predictor of a person's behavior. In addition to this, many recent studies on interpersonal behavior have pointed out that the majority of our interactions take place within the context of roles (e.g., Jones \& Thibaut, 1958). It appears then that the more efficient interaction will result from utilization of role cues mediated by role stereotypes rather than ethnic cues and ethnic stereotypes. The relative importance of these two cognitive sets may therefore, have implications both for ethnic perception as a process and for ethnic group relations. 


\section{EXPERTMENT I}

\section{Introduction}

As a first step towards formulating a pattern for the interaction of role and ethnic stereotypes in person perception, the present study will involve $\underline{S}$ who have little or no contact with the ethnic group in question. It was hoped that the selection of these isolated groups would enhance the possibility for discovering differences in in-group and out-group perception and thereby provide an important baseline with which to compare other groups who have had more contact with the ethnic group.

of major interest in this study is how ethnic in-group perception differs from ethnic out-group perception in terms of the differential importance of role and ethnic stereotypes. In order to generalize the findings to more than one in-group and out-group, two different ethnic groups of $\underline{S} s$, English Canadian and French Canadian, were used, both isolated from contact with the other.

It was hoped that the same pattern of stereotype use would be found with both groups in order to allow for generalizations about the process of ethnic perception. However, it is also likely that there would be some differences within this pattern in the stereotypes held by these two cultural groups reflecting differences in the way they perceive their environment. The way in which a particular ethnic group perceives its social environment, or its "subjective culture ", has been studied by Triandis, Vassiliou, and Nassiakou (1968). They find evidence that ethnic groups have unique ways of perceiving their social world and these differences may be reflected in the specific stereotypes held by French and English Canadians in the present study. A comparison was made, therefore, of French and 
English Canadians' perceptions of their own and the other's ethnic group, and as well their perceptions of certain roles. Two specific roles, highly relevant to the Ss' everyday lives were used.

\section{Method}

\section{Subjects}

The $\underline{\text { ss }}$ for this experiment were 46 high school students from Barraute, a town in northern Quebec, and 46 students of similar age from Smith's Falls, a city located in Ontario near Ottawa. The Barraute $\underline{S}$ attended a Catholic French school and identified themselves as French Canadians, and the Smith's Falls Ss were enrolled in a Catholic English school and identified themselves as English Canadians. Smith's Falls and Barraute are also comparable towns in terms of being ethnically one-sided: There are very few French Canadians in Smith's Falls and very few English Canadians in Barraute.

\section{Procedure}

The Ss were administered a questionnaire during one of their classes at school. It was composed of the three following sections:

\section{1) Trait Questionnaire}

The trait questionnaire consisted of eight concepts each printed at the top of a separate page, and a list of 30 adjective dimensions placed under each concept.

The eight concepts used for this study included two ethnic labels ENGLISH CANADIAN and FRENCH CANADIAN, two roles STUDENT and TEACHER, and four combinations of these concepts, ENGLISH CANADIAN STUDENT, FRENCH CANADIAN STUDENT, ENGLISH CANADIAN TEACHER, and FRENCH CANADIAN TEACHER. Half the Ss in the English Canadian sample rated the combination concepts with the ethnic label first (e.g., French Canadian student) and the other half received the 
role label first (student French Canadian) to control for order effects. Ss in the French Canadian sample rated all combinations with the role first (e.g., étudiant canadien français). The adjectives were placed in a different order for each concept, and the concepts were randomized with the restriction that single concepts were always rated before the combinations.

The adjectives were selected so that there were five relevant trait adjectives for each of the role and ethnic concepts, five that were relevant to all the concepts, and five that were of an evaluative nature (see Appendix 1). Initially these adjectives were taken from 12 French and 12 English students' verbal descriptions of the two ethnic groups and the two roles, elicited in an informal discussion with two students at a time.

The rating scale was a $15 \mathrm{~cm}$. straight line labelled at one end "not at all" and at the other "extremely". For each adjective $\underline{S}$ made his rating by placing a slash through the point in the line which corresponded to his impression of the concept. The use of this straight line measurement technique as opposed to the usual category scale allowed for a more precise measure of Ss judgments. Ss had essentially 150 response alternatives since ratings were measured in centimeters to one decimal place. Having responses on a continum also meant that we could later transform the scores to a normal distribution insuring that the means and variances would be independent.

The questionnaire was prepared initially in French. Two bilinguals then composed an English version of the questionnaire by means of a back translation procedure.

\section{2) Behavior Questionnaire}

The second section consisted of behavior scales. A role concept was printed at the top of each page, and under it were listed five behaviors 
relevant to that particular role. They were specific behaviors, generally referring to some interaction with a complementary role and were selected through informal discussion with French and English Canadian students. The behaviors chosen are presented in Appendix 1, but an example of one for the STUDENT role is, "A student is regarded as a number rather than as an individual by his teachers." The Ss rated the roles STUDENT and TEACHER along the five behavior dimensions appropriate to each of them. They then rated ENGLISH CANADIAN STUDENT and FRENCH CANADIAN STUDENT along the same dimensions as they rated STUDENT, and rated ENGLISH CANADIAN TEACHER and FRENCH CANADIAN TEACHER along the same behavior dimensions as they did for TEACHER. Randomization of concepts and behaviors followed the same pattern as for the trait questionnaire. The same straight line rating procedure was used, this time with the labels "I completely agree" and "I completely disagree", placed at the ends of the line.

\section{3) Contact Questionnaire}

The purpose of the third section was to provide empirical support for our selection of these two subject samples as representing ethnically isolated groups. In general, it determined the nature and frequency of contact $\underline{S}$ had with his own and with the other ethnic group. The $\underline{S}$ was presented with 24 statements describing a certain type of contact, and for each one he was to put a mark through a line somewhere between the ends labelled "never" and "very frequent1y" to represent the frequency with which he had this type of contact. The 24 statements systematically varied along three dimensions: The ethnic group of the person with whom the contact is--English Canadian or French Canadian; the place of contact--at school, in the neighborhood, or in social groups; and the type of contact--encounter, formal interaction, 
informal interaction, and intimate interaction. The four types of contact were defined on the questionnaire so that they would be consistently used by all Ss. One of the statements, for example, is, "I informally interact with French Canadians in my neighborhood."

Method of Analysis

\section{1) Trait Questionaire}

The raw data for this first section was subjected to two different types of analysis. Firstly, to determine the content of the role and ethnic stereotypes, a modification of a procedure developed by Gardner, Wonnacott, and Taylor (1968) was used. To delineate the stereotype, a separate $\underline{t}$ test was performed for each of the 30 adjectives as they applied to each of the eight concepts. The $\underline{t}$ scores $[(\bar{x}-u) \sqrt{N / S}]$ were used instead of simple means because a $\underline{t}$ score takes into account both the mean rating of the responses and the variance. Previous assessments of stereotypes were only interested in measuring frequency because the $\underline{S} s^{\prime}$ responses were in the form of a dichotomous YES or NO as to the applicability of that trait to a particular ethnic group. Frequency of YES responses, therefore, gave a measure of the degree of consensus on the attribution of that particular trait. Gardner, Wonnacott, and Taylor (1968), however, made use of the semantic differential and thereby gave the Ss more than two response alternatives by allowing them 7 categories to rate the degree to which the ethnic group possessed each trait. Therefore, not only consensus as measured by the variance in this case, but magnitude of response, measured by the mean, is necessary. Since stereotypes are definite characteristics attributed to a group for which there exists a high degree of consensus, the degree of polarity described by. the $\underline{t}$ is a good measure of stereotypy. 
The modification of this procedure used in the present study involved transforming each score by taking the arc $\sin \sqrt{\mathrm{X} / 15}$ and then performing the above polarity analysis on these transformed scores. The purpose of the transformation was to make the response distributions more normal, with means and variances independent. This is one of the assumptions underlying the $\underline{t}$ statistic which is especially important for stereotype assessment because those traits included in the stereotype are those where the rating was close to the limit of the continuum and it is reasonable to expect. small variance under these conditions due to scale restrictions rather than actual consensus among Ss. The performance of a transformation, therefore, insures that a true measure of variance is obtained.

Secondly, in order to look at the use of role and ethnic cues in person perception, a multiple regression was performed on the data. $\underline{S} s^{\prime}$ ratings on each of the complex stimuli (e.g., FRENCH CANADIAN TEACHER) was used as the dependent variable, and ratings on the role and ethnic concepts singly (e.g., FRENCH CANADIAN and TEACHER) served as the two independent variables. This calculation yielded standardized beta weights indicating the relative weights given to the ratings of the role and ethnic concepts to produce a value which best fit the actual rating of that combination stimulus. It was also possible to determine how much of the variance was attributable to the regression, in other words, how good the two independent scores were at predicting the dependent one. A separate regression analysis was performed on each adjective scale as it applied to each combination concept. For each concept, the scales for which the role cue beta weight was larger were totalled. The same was done for scales where the ethnic cue beta weight was larger. A comparison of these scores indicated whether the ethnic cue or the role cue was more important for the rating of that concept. 


\section{2) Behavior Questionnaire}

The two variables of interest in this section are ethnicity of $\underline{S}$ (French Canadian vs. English Canadian) and ethnicity of the person occupying the role that is being rated (Neutral vs. French Canadian vs. English Canadian). Therefore, five separate $2 \times 3$ analyses of variance were performed on the English $\underline{S}$ and the French $\underline{S}$ responses to the five different behavior dimensions for STUDENT and its ethnic combinations, and then again for the behavior dimensions for TEACHER and its ethnic combinations. This analysis would indicate changes in $\underline{S} s^{\prime}$ ratings of the two roles depending on whether an English Canadian or a French Canadian was occupying it, and the differences between French Canadian $\underline{S} s^{\prime}$ and English Canadian $\underline{S} s^{\prime}$ ratings of these roles.

3) Contact Questionnaire

The contact section was analyzed using a $2 \times 2 \times 3 \times 4$ analysis of variance with repeated measures. The factors were ethnicity of $\underline{S}$ (French Canadian vs. English Canadian), ethnicity of contact (French Canadian vs. English Canadian), location of contact (school, neighborhood, social groups), and type of contact (encounter, formal, informal, intimate).

\section{Results}

\section{1) Trait Questionnaire}

The content of the two ethnic and two role stereotypes and their combinations were determined for the English Canadian and French Canadian samples using the $\underline{t}$ distributions of the transformed scores. The ten adjectives with the most significant $\underline{t}$ values for each of the eight concepts are listed in Tables 1 and 2. For the English Canadian sample these t's range from 20.07 to 38.43 ; and for the French Canadian sample they range from 25.68 to 50.08. In terms of frequency distribution, this meant that for the very top-ranking adjectives approximately $85 \%$ of the responses fell in the extreme third of 
the line, and for adjectives in the ninth and tenth spot approximately 67\% were within this extreme range for the French Canadian sample and $60 \%$ for the English Canadian sample. So it is reasonable to assume that S $\mathbf{s}^{\prime}$ ratings on these adjectives show a high degree of polarity.(see Figure 1).

English and French Canadian students seem to have similar impressions of the roles STUDENT and TEACHER--the t's for these two concepts correlated .56 and .63 respectively. There was considerable agreement on the active qualities of STUDENT, such as dynamic, proud, ambitious, bold, and demanding; and on the intellectual qualities, such as educated, creative, and competent. They were also described in positive evaluative terms as likeable, humane, and generous. TEACHERS were also described in intellectual terms by both groups of $\underline{S}$, but the French Canadian $\underline{S}$ stressed the active qualities such as ambitious, dominant, dynamic, demanding, and bold; whereas the English Canadian Ss showed polarized ratings on the positive evaluative qualities such as humane, honest, generous, sincere, and likeable.

Responses to the ethnic group labels also display a high degree of stereotypy; however, French and English Canadian Ss differed slightly in the content of the stereotype. English Canadian Ss think of themselves as likeable, competent, proud, and ambitious; and think of French Canadians as proud, emotional, dissenting, and demanding. On the other hand, the French

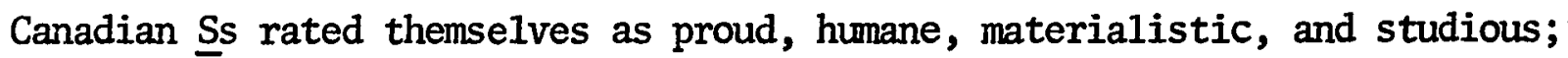
and rated English Canadians as educated, dominant, ambitious, and authoritarian.

The subjective impressions that these two groups of Ss have of both English Canadians and French Canadians do not seem to coincide. The correlation of English Canadian $\underline{S} s^{\prime} \underline{t}$ values with French Canadian $\underline{S} s^{\prime} \underline{t}$ values on the concept ENGLISH CANADIAN was . 36 and on the concept FRENCH CANADIAN 

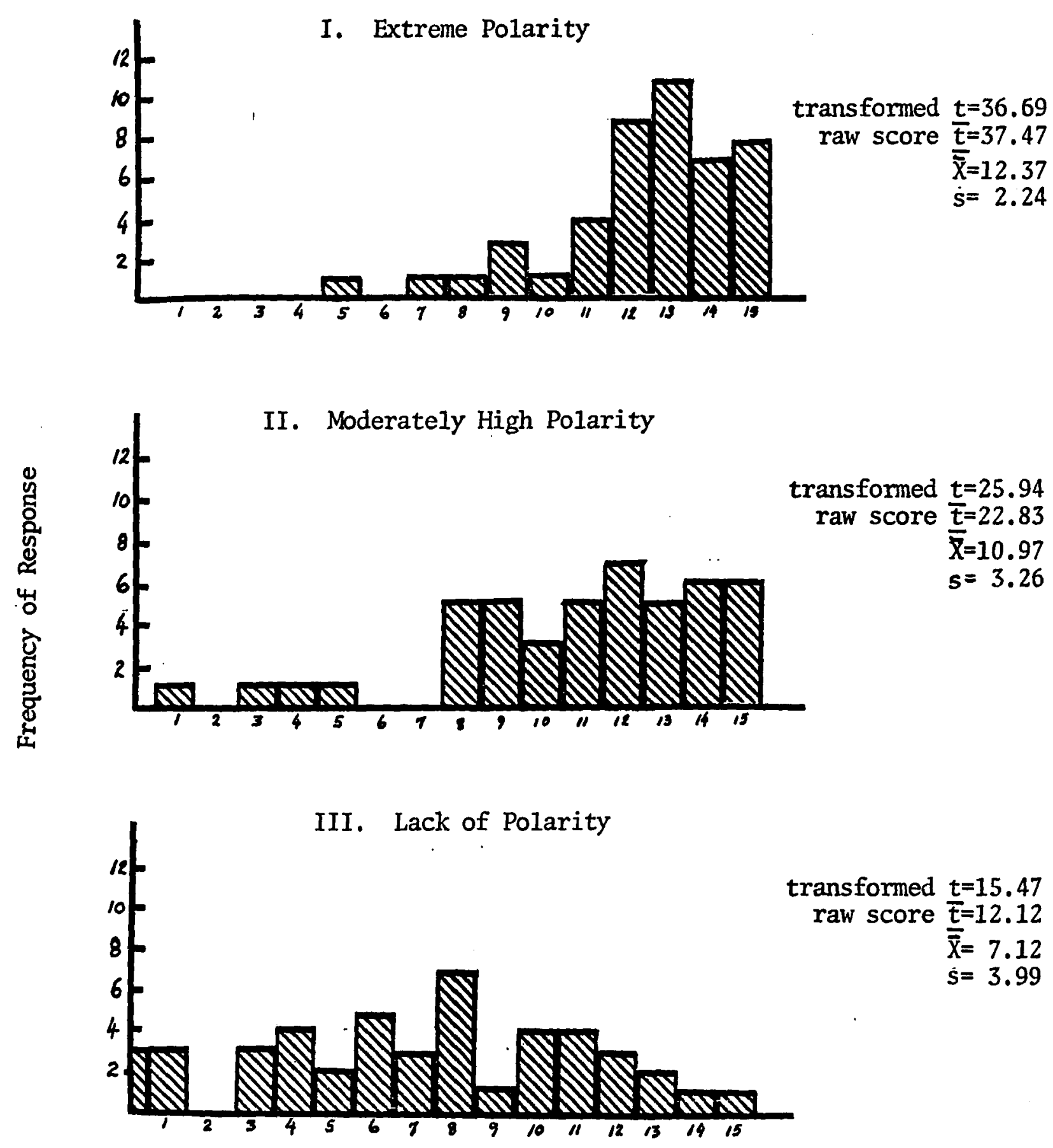

$15 \mathrm{~cm}$. continuum broken down into equal intervals

Figure 1. Response distributions on three selected adjective scales illustrating 3 different degrees of polarity. 
was .35; both were not significantly different from zero at the .05 level. This discrepancy stands out in contrast to the similarity found between English and French Canadian Ss' impressions of the roles STUDENT and TEACHER. In this case, the role perception aspect of subjective culture shows more congruence than ethnic group perception.

Adjectives showing a high degree of polarity for the ethnic-role combination ratings are presented in Table 2. The French Canadian sample produced higher $\underline{t}$ values, but in both cases the $\underline{t}$ 's were very significant. English Canadian Ss considered ENGLISH CANADIAN STUDENTS to be, for example, ambitious, educated, likeable, and proud; and FRENCH CANADIAN STUDENTS to be emotional, demanding, bold, and dominant. On the other hand, the French Canadian Ss thought of ENGLISH CANADIAN STUDENTS as educated, competent, creative, and dynamic; and of FRENCH CANADIAN STUDENTS as proud, dynamic, educated, and bold. For the TEACHER combination stimuli, the descriptions of ENGLISH CANADIAN TEACHER and FRENCH CANADIAN TEACHER are very similar. The English Canadian Ss emphasized qualities like educated, ambitious, proud, generous, and competent for both these concepts. The French Canadian Ss rated ENGLISH CANADIAN TEACHERS high on the adjectives ambitious, educated, dynamic, and studious; and FRENCH CANADIAN TEACHERS high on bold, hardworking, competent, and educated.

The second form of analysis, the multiple regression, produced standardized beta weights which indicate how much $\underline{S}$ are using the role cue and the ethnic cue when making their ratings of the combination concept (see Appendix 2). The mean multiple correlation was .48 for the French Canadian sample and .52 for the English Canadian one, an indication that a close fit was achieved between the weighted ratings on the two independent variables (responses to single labels) and the rating on the dependent variable (combination concept). In $85 \%$ of the scales, a significant $(\mathrm{p}<.05)$ amount 
of the variation could be attributed to the regression of the two role and ethnic variables on the combination stimulus variable. Summation of the scales which showed role cue dominance and ethnic cue dominance for each concept, resulted in the following pattern (see Table 3). The French Canadian Ss had greater ethnic cue beta weights on a large proportion of the scales for the concepts ENGLISH CANADIAN STUDENT and ENGLISH CANADIAN TEACHER. On the other hand, role beta weights were larger on the majority of scales for the concepts FRENCH CANADIAN STUDENT and FRENCH CANADIAN TEACHER. The pattern is not so clear-cut for the English Canadian Ss. The concept FRENCH CANADIAN STUDENT provoked a large proportion of ethnic-dominant weights and the concept ENGLISH CANADIAN TEACHER showed a majority of role-dominant weights. These two results are diametrically opposite to the French Canadian results. But in the cases of the concepts ENGLISH CANADIAN STUDENT and FRENCH CANADIAN TEACHER an equal number of scales show role dominance as ethnic dominance. Except for these last two results, the beta weight analysis can be summarized as indicating a distinction between the use of role and ethnic cues for French Canadians and for English Canadians: For in-group perceptions, role cues were used predominantly; and for out-group perceptions, ethnic cues were used more.

2) Behavior Questionnaire

Analyses of the behavior ratings by means of a $2 \times 3$ analysis of variance pointed out three STUDENT behaviors and two TEACHER behaviors that were rated differently by French Canadian and English Canadian Ss. The English Canadian students disagreed more with the statements, "A student is regarded as a number rather than as an individual by his teacher." and "Teachers expect that students will swallow everything they tell them."; and agreed more with the statement, "It is easy for a student to discuss things 
with a teacher." The two TEACHER behaviors, "Teachers show favoritism toward students they prefer." and "Teachers are understanding in regard to the problems of their students." were rated with more agreement by the English Canadian Ss than by the French Canadian Ss.

Two out of the five STUDENT behaviors and one TEACHER behavior showed a significant interaction between ethnicity of subject and ethnicity of role. These were for the statements, "A student is regarded as a number rather than as an individual by his teachers." $(F=9.10 ; \mathrm{df}=1,90 ; \mathrm{p}<.01)$, "Teachers expect that students will swallow everything they tell them." ( $F=6.31$; $d f=1,90 ; p<.05)$, and "Teachers are dedicated to their students." (F=6.00; $d f=1,90 ; p<.05)$. These three interactions are plotted in Figure 2 and show

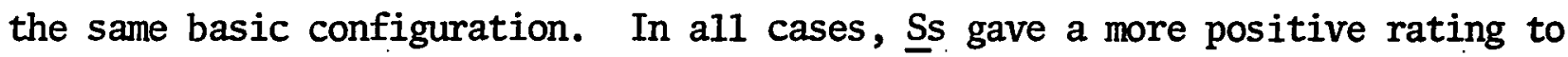
the role when occupied by a member of their own ethnic group than when occupied by an out-group member.

\section{3) Contact Questionnaire}

Several effects were obtained for the 4-way analysis of variance of Ss' ratings of contact; however only the interaction involving ethnic group of $\underline{S}$ and ethnic group of contact is of interest for the present study. This interaction is significant $(F=568.99 ; d f=1,90 ; p<.01)$ and is plotted in Figure 3. The configuration indicates that our two subject groups were indeed ethnically isolated from contact with the other ethnic group.

\section{Discussion}

The results of the $\underline{t}$ tests performed on the single labels seem to indicate that people do have at their disposal a precise set of cognitions about these role and ethnic groups. From the polarity analysis emerges a cluster of highly polarized adjectives which reflect the ideas, beliefs, or expectancies 


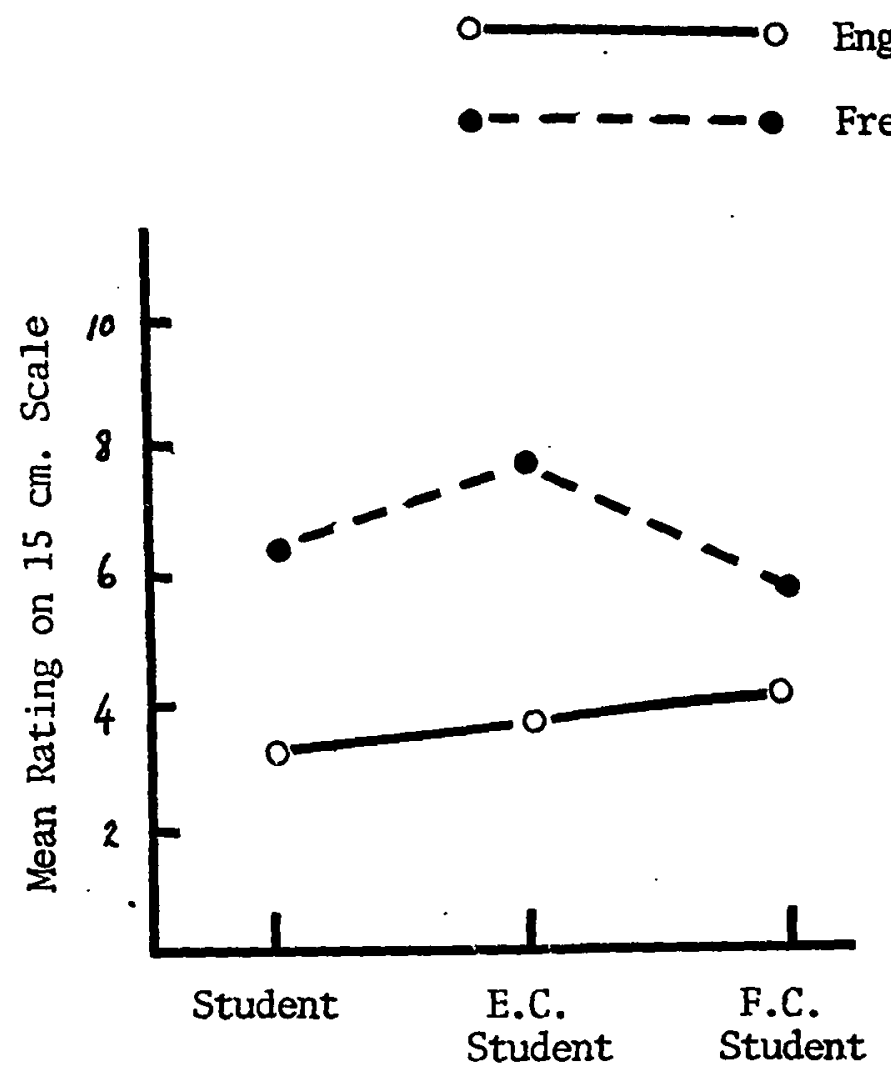

English Canadian Ss

French Canadian Ss number rather than as an individual by his teachers.

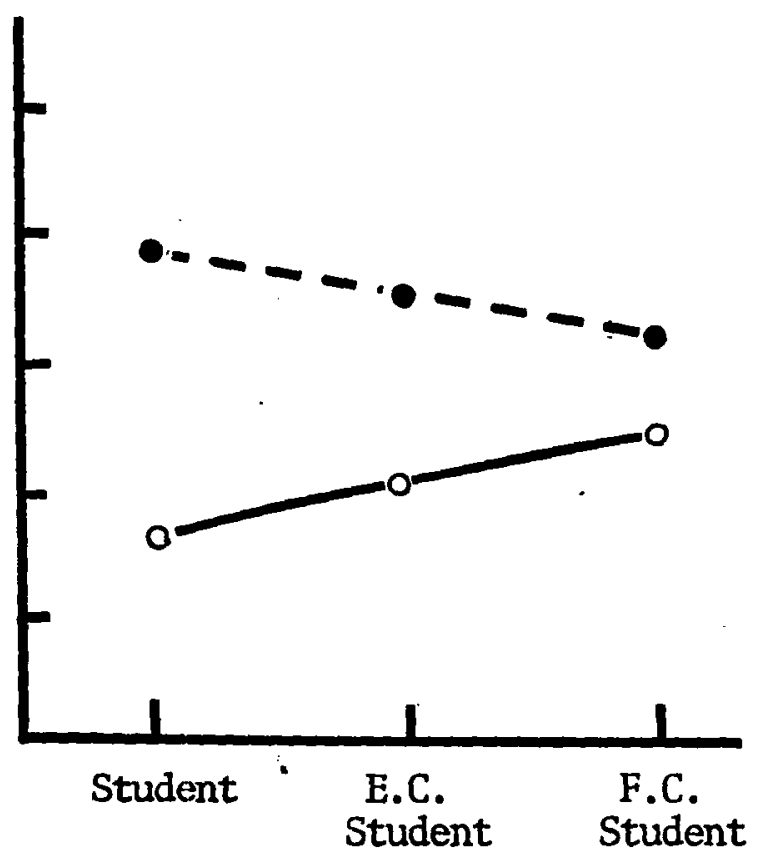

II. Teachers expect that students will swallow everything they tell them.

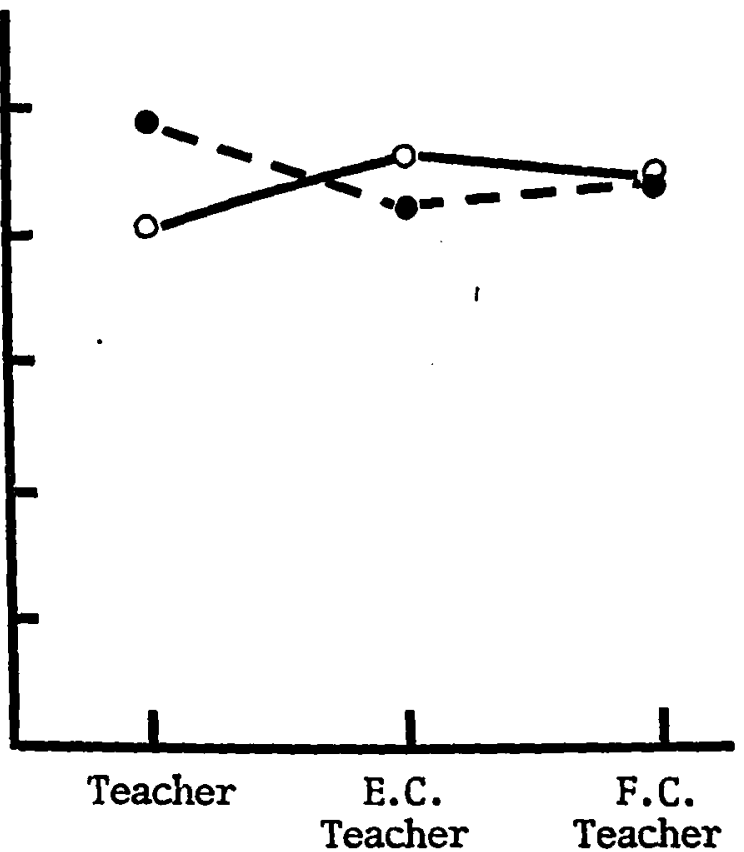

III. Teachers are dedicated to their students.

Figure 2. Mean ratings for French Canadian and English Canadian Ss on the above 3 Behavior Dimensions. 


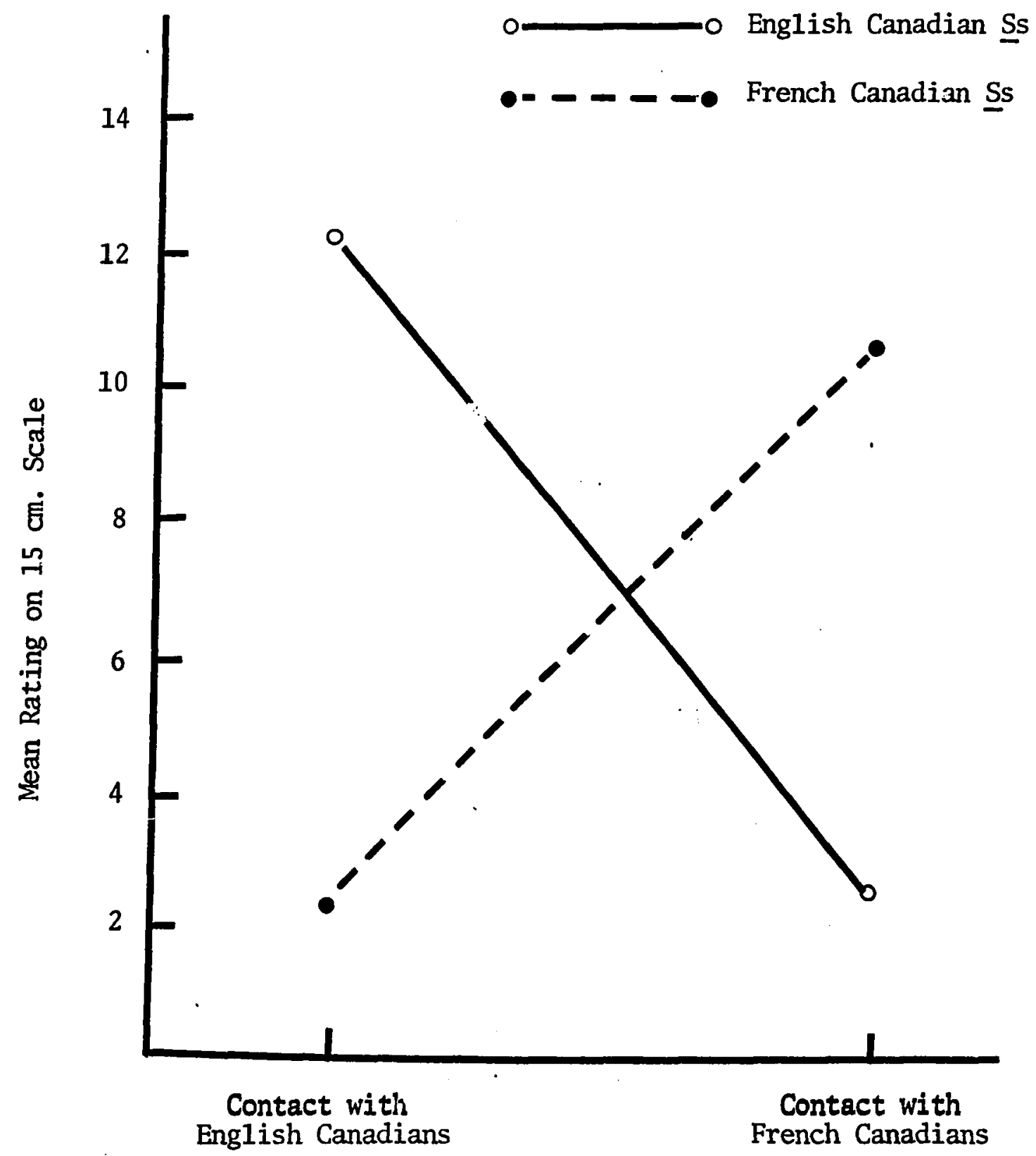

Figure 3. Mean ratings for French Canadian and English Canadian Ss on Contact Questionnaire. 
that people have about these groups in general. In this sense, they constitute social stereotypes.

It is interesting to note that these particular French Canadian and English Canadian students have very similar impressions of the roles STUDENT and TEACHER as assessed by these adjectives. They both describe these roles in adjectives suggesting intellectualism, dynamism, and humaneness, with slight variations on the degree to which each of these is emphasized. In contrast, French Canadian and English Canadian students did not agree in the way they rated the two ethnic groups, ENGLISH CANADIAN and FRENCH CANADIAN. The behavioral dimensions point out a few more differences between the two groups mainly in terms of a few specific behaviors that teachers and students (French Canadian and English Canadian) display toward one another. In all cases, the differences show up a tendency for an ethnocentric subjective culture in rating their own ethnic group and their own teachers and students more favorably than those of the appropriate out-group.

When the cues for both role and ethnic stereotypes were combined in a complex stimulus, an interesting pattern of person perception emerged. Just how much each cue--role and ethnic--contributes to the perception of a complex stimulus can be formulated in terms of the multiple regression beta weights. The information called forth by each cue is essentially the set of cognitions or the stereotype about that particular role or ethnic group. When a person is given the choice of using either source of information in his perceptions of a complex person-stimulus, which source will he utilize more--role stereotypes or ethnic stereotypes?

When describing a role (STUDENT or TEACHER) that is occupied by someone from their own ethnic group, the French Canadian Ss used their stereotypes about that particular role. When the role is occupied by an English 
Canadian, these same $\underline{S}$ s used their ethnic stereotypes when rating the concept. The English Canadian Ss also used ethnic stereotypes when rating the STUDENT role occupied by an out-group member (in this case a French Canadian) but used role information when perceiving an in-group (English Canadian) TEACHER. For six out of the eight concept ratings, perceptions of the role-ethnic combinations fall into a pattern of out-group perceptions involving the use of ethnic stereotypes predominantly and in-group perceptions relying on role stereotypes. In other words, perception of persons from another ethnic group is being mediated Iargely by ethnic stereotypes; whereas perception of persons from one's own ethnic group is being influenced mainly by role stereotypes.

The use of two ethnically isolated groups in the present study has resulted in the emergence of a pattern of ethnic perception and this pattern has implications for interaction between two ethnic groups. An assessment of French Canadian and English Canadian students' stereotypes indicated that their ideas of what a teacher and student are like coincide, but that their expectations of French Canadians and English Canadians differ. It seems reasonable, therefore, to assume that more efficient interaction will result from the use of these two role stereotypes rather than the two ethnic stereotypes. In fact, the pattern that emerges points out a desensitization towards ethnic cues and a reliance on the role cues for in-group perception where one would expect to find relatively efficient interaction. On the other hand, the pattern indicates an emphasis on ethnic cues for out-group perception, perhaps leading to relatively less efficient interaction. 
EXPERTMENT 2

\section{Introduction}

In Experiment 1 an attempt was made to formulate a pattern for the interaction of role and ethnic stereotypes as they operate in in-group and out-group perception. The results suggested that for in-group perception $\underline{S}$ used role cues mediated by role stereotypes predominantly, whereas for out-group perception they relied more on ethnic cues and ethnic stereotypes. Previously, it was hypothesized that the operation of different processes for in-group and out-group perception has negative implications for efficient cross-cultural interaction. However, the person perception pattern which emerged was based on the responses of two samples found to be ethnically isolated. As such, the results provide a good baseline from which to now study the more socially relevant situation where two ethnic groups share the same social environment. A1though there have been few precise predictions concerning the effects of contact on ethnic perception (Pool, 1965; Triandis \& Vassiliou, 1967; and Amir, 1969), judging from the results of Experiment 1 where $\underline{S}$ s used role information when perceiving ethnic groups with which they had a lot of contact (i.e., their in-group), it seems likely that more experience with the out-group will result in a greater use of role rather than ethnic cues.

The present study, therefore, focused on two samples of English Canadians, one having contact, the other no contact with French Canadians. A different set of roles was also used to determine how well the findings of Experiment 1 can be generalized to other more informal social roles. For this reason the complementary roles MALE and FEMALE were used instead of STUDENT and TEACHER. 


\section{Method}

Subjects:

The $\underline{S}$ for this experiment were 67 adults all of whom identified themselves as English Canadians. Thirty-three of the Ss (22 male, 11 female) worked in the programming department of a large Montreal firm, while the remaining 34 Ss (24 male, 10 female) were employed in programming departments of similar firms located in Toronto. The Toronto sample was selected because this city has a very small French Canadian population when compared to Montreal.

Procedure:

The $\underline{S}$ sere administered a questionnaire which contained two sections: section 1 was a Trait Questionnaire and was similar to the one employed in Experiment 1; section 2 was a Contact Questionnaire identical to that used in the previous study with "school" changed to "job".

The first section consisted of eight concepts with a list of 25 adjectives (some different from the other study) under each concept. The eight concepts used in this study consisted of the same two ethnic labels ENGLISH CANADIAN and FRENCH CANADIAN, two more informal social roles MALE and FEMALE, and four combinations of these concepts, ENGLISH CANADIAN MAEE, FRENCH CANADIAN MALE, ENGLISH CANADIAN FEMALE, and FRENCH CANADIAN FEMALE. Half the subjects rated the combination concepts with the ethnic label first (e.g., French Canadian male) and the other half received the role label first (male French Canadian) to control for order effects. Again the adjectives and concepts were randomized.

The 25 adjectives used were taken from a study by Gardner, Wonnacott, and Taylor (1968) which examined French Canadian stereotypes, from the Osgood, 
Suci, and Tannenbaum (1957) semantic differential factors, and from Friedman and Gladden's (1964) assessment of social roles (see Appendix 3). Only one adjective was used from a bi-polar pair because in many cases it was difficult to select true opposites.

The rating scale was a $15 \mathrm{~cm}$. straight line labelled at one end "not at all" and at the other "very definitely". Ss again responded by putting a mark through the line.

Method of Analysis:

The same two analyses were performed on the data from the trait questionnaire as were used in Experiment 1--t tests on scores transformed with arc sin $\sqrt{\mathrm{X} / 15}$, and multiple regressions.

In addition, because of the complementary nature of the roles chosen, a set of correlations were computed between the $\underline{t}$ values for the four combination concepts. The purpose was to determine for each group which combination concepts were rated similarly--those with role in common or those with ethnicity in common. As a first step, those concepts with ethnicity in common were correlated (e.g., FRENCH CANADIAN MALE with FRENCH CANADIAN FEMALE). If

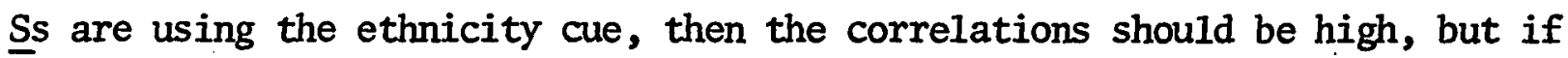
they are using the role cue, they would be low. Secondly, those concepts with the MALE role in cormon were correlated and similarly concepts with the FEMALE role in common were correlated (e.g., ENGLISH CANADIAN FEMALE with FRENCH CANADIAN FEMALE). If $\underline{S}$ are focusing on the role, then both these correlations should be high. If, on the other hand, they are focusing on ethnicity, then the correlations will be low.

The contact responses were analyzed as previously by means of a 4-way analysis of variance. 


\section{Results}

The content of the four ethnic and role stereotypes and their combinations were determined separately for the contact and no-contact samples. Tables 4 and 5 rank the ten adjectives with the most significant $\underline{t}$ values for each of the eight concepts. As in the previous study, the $\underline{t}$ 's presented are those derived from the transformed scores. The contact and no-contact groups are shown separately here although a polarity analysis was also performed on the two groups together because they appeared so similar. In this combined analysis, MALES were thought, for example, to be intelligent, strong, dominant, and competitive; and FEMALES sociable, sensitive, talkative, and colorful. It can be noted that the two samples' descriptions of males have many adjectives in common, but their ideas about females are not quite so similar.

As in the previous study, responses to the concepts ENGLISH CANADIAN and FRENCH CANADIAN were highly polarized. The $\underline{S}$ characterized ENGLISH CANADIANS as generally intelligent, logical, dominant, and strong. On the other hand, FRENCH CANADIANS were rated as affectionate, talkative, artistic, and sensitive. One interesting difference between the no-contact group's stereotype of FRENCH CANADIANS and the contact group's stereotype is that adjectives like impulsive and religious are found in the former's cognition, whereas strong and competitive are part of the latter's stereotype of FRENCH CANADIANS.

The adjectives for the ethnic-role combinations, presented in Table 5, also show considerable polarity, with $\underline{t}$ values as high as for the labels singly. Each of the four combinations was rated in terms of a descriptive Gestalt of its own, which nevertheless, appeared to draw mainly from the 
stimuli composing it. ENGLISH CANADIAN MALES were considered to be competitive, dominant, logical, and strong; whereas FRENCH CANADIAN MALES were thought of as sociable, emotional, proud, and affectionate. Ss rated ENGLISH CANADIAN FEMALES as talkative, sociable, proud, and artistic; and FRENCH CANADIAN FEMALES as affectionate, talkative, sociable, and artistic.

As a first level analysis of the relative importance of ethnic and role cues, correlation coefficients for concepts with role in common and ethnicity in common were compared for the contact and no-contact groups. The correlation between the $\underline{t}$ values for concepts with ethnic affiliation in common, and for concepts with similar roles but different ethnicity are presented in Table 6. The FRENCH CANADIAN concepts were highly correlated despite the difference in roles; however, this was not the case for the ENGLISH CANADIAN concepts. The high correlation for the FRENCH CANADIAN pair indicates that Ss were aware of the out-group affiliation that the concepts had in common. On the other hand, the low correlation in the ENGLISH CANADIAN pair suggests that the English Canadian $\underline{S}$ were focusing on role differences rather than on the cormon English Canadian background.

The correlations between concepts with a common role but different ethnicity show a division on the basis of contact versus no-contact. ENGLISH and FRENCH CANADIAN MALES were rated similarly, as were both FEMALE concepts, by the contact group but not by the no-contact group. The contact group seems to be drawing more from role information and not from ethnic cues as compared with the no-contact group.

For this first level analysis, the general pattern of correlations suggests, as in the previous study, that ethnic cues are more important than role cues for out-group perception while the opposite is true for the perception of in-group members. Furthermore, it highlights one major difference 
between the two groups; that is, the contact sample shows a greater awareness of the role similarity between stimuli of different ethnicity than does the no-contact sample.

The multiple regression analysis (see Appendix 4) summarized in Table 7, explores more completely $\underline{S} s^{\prime}$ use of role and ethnic stereotypes. Although some of the correlations did not reach significance, in the majority of cases, the multiple correlations were high, and a significant $(\mathrm{p}<.05)$ amount of the variation for $65 \%$ of the scales could be attributed to the regression of the two role and ethnic independent variables on the combination stimulus dependent variable. The results are very similar for both contact and no-contact samples; there were an equal number of role- and ethnic- dominant scales for the ENGLISH CANADIAN MALE concept and a greater proportion of role dominance in the beta weights for ENGLISH CANADIAN FEMALE. By contrast a high proportion of ethnic-dominant weights were found in both the FRENCH CANADIAN MALE and FRENCH CANADIAN FEMALE ratings. This seems to outline a pattern very similar to the one found in Experiment 1: for in-group perceptions (in this case English Canadian) role cues were used predominantly; and for out-group perceptions (French Canadian) ethnic cues dominated.

The results of the contact analysis indicate that the Montreal $\underline{S}$ did have more contact with French Canadians than did the Toronto Ss. The interaction between subject group and ethnicity of contact as plotted in Figure 4, was significant at the .01 level $(\mathrm{F}=13.78 ; \mathrm{df}=1,64 ; \mathrm{p}<.01)$. However, the amount and nature of this contact with French Canadians was not as might be expected. The mean rating for the Toronto $\underline{S}$ s having contact with French Canadians was 2.0 and for the Montreal Ss was only 4.1. In addition, a large portion of the Montrealer's contact with French Canadians seems to be of an encounter nature $(\bar{X}=5.96)$ as compared with formal interaction $(\bar{X}=3.53)$, informal interaction $(\bar{X}=4.31)$, and intimate interaction $(\bar{X}=2.78)$. 


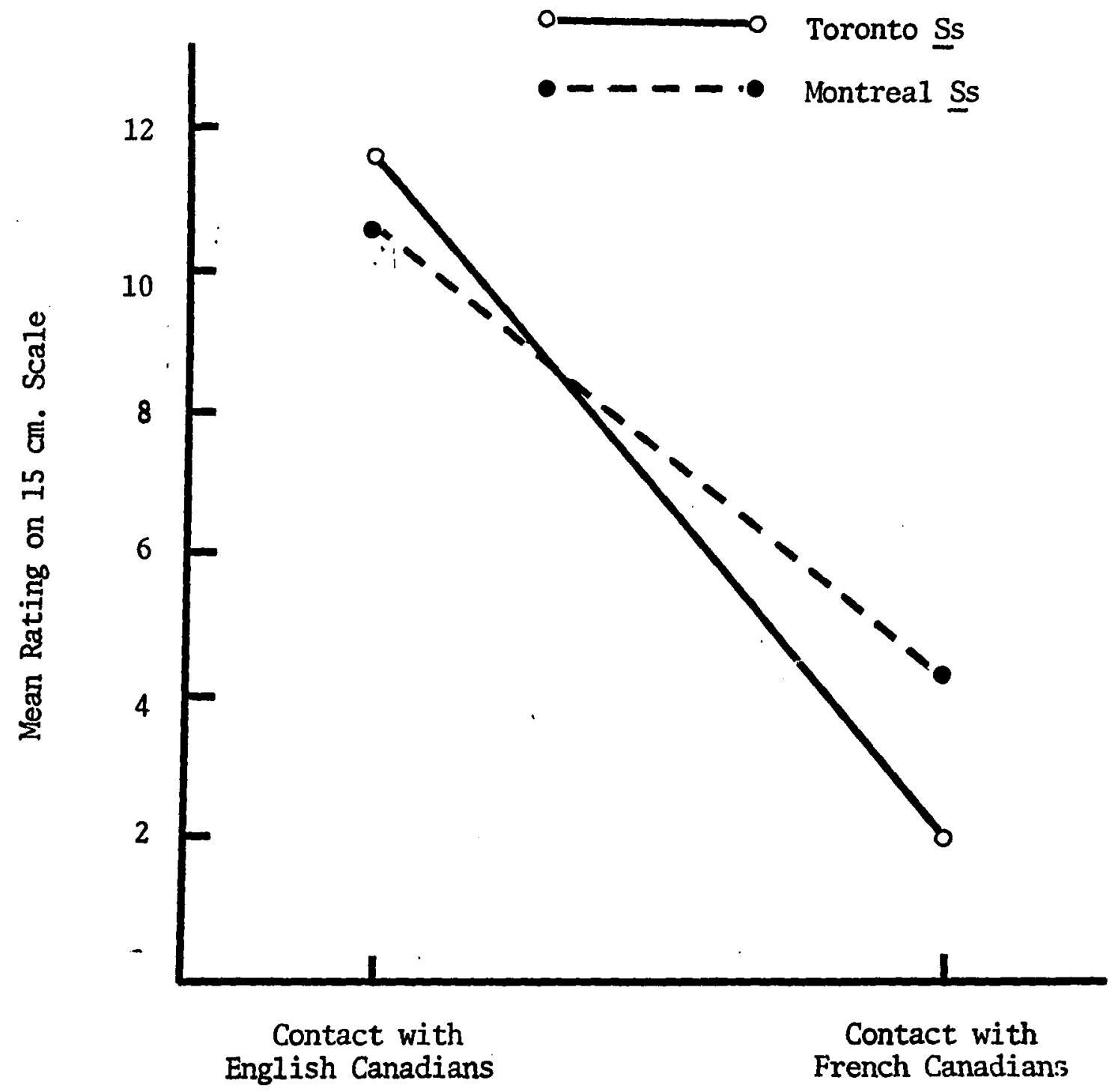

Figure.4. Mean ratings for French Canadian and English Canadian Ss on on Contact Questionnaire. 


\section{Discussion}

The results will be discussed in three sections: The first concerning role and ethnic stereotypes as elicited by single labels, the second concerning the relative importance of each stereotype as it functions in person perception, and the third concerning the effects of contact with an ethnic group on this perception.

The stereotypes or set of cognitions that these two groups have about English Canadians and French Canadians is similar in many respects to the stereotype held by the English Canadian Ss as assessed in Experiment 1. Apparent in both groups' stereotype is a cluster concerned with competence, pride, dominance, and the work ethnic (competitive etc.) for English Canadians, and a cluster concerned with emotion, creativity, pride, and revolt for French Canadians.

One interesting result of the stereotype analysis is the difference in Ss' expectancies about the MALE and FEMALE roles, both on a descriptive level, as evidenced in the stereotype tables, and on a statistical level. The correlations between the $\underline{t}$ values for the concepts MALE and FEMALE were negative (reaching significance in the contact sample, but not in the no-contact one). This suggests that the adjectives chosen were sensitive enough to detect the complementary nature of these roles. By contrast, the ethnic stereotypes do not appear to have the same complementary nature as the role stereotypes.

The correlations between the $\underline{t}$ values for ENGLISH CANADIAN and FRENCH CANADIAN were close to zero (either slightly positive or slightly negative). In the previous study they correlated zero for the French Canadian group and positive for the English Canadian group. This implies that ethnic stereotypes are not necessarily a means of classifying people which emphasize differences between 
groups, as has sometimes been suggested (cf., Campbell, 1967; Tajfe1, Sheikh, \& Gardner, 1964). The ethnic groups were not thought of in as contrasting terms as were the role stereotypes. It may be that these ethnic stereotypes are simply independent cognitions.

When both role and ethnic cues are provided for the $\underline{S}$ 's perception of the concept, the responses of both groups demonstrate the same clear pattern.

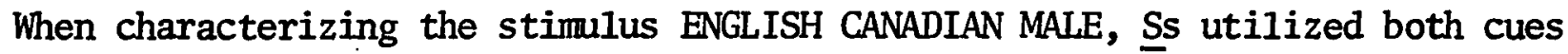
equally; this is probably due to the fact that the stereotypes for ENGLISH CANADIAN and for MALE are very similar, their $\underline{t}$ values were found to correlate .62 for the no-contact sample and .77 for the contact one. The same was true for thee concept ENGLISH CANADIAN STUDENT in Experiment 1, where the English Canadian students used both cues equally. In this case as well the correlation of these two concepts was higher than for any other pair. For the ENGLISH CANADIAN FEMALE stimulus, the role cue contributed more to $\underline{S} s^{\prime}$ perceptions on the majority of adjectives. For the stimuli FRENCH CANADIAN MALE and FRENCH CANADIAN FEMALE, ethnic information dominated for most adjectives. For both samples, the characteristics that French Canadians have in common seemed to override major differences in sex role. But when perceiving someone of their own ethnic group, Ss were more aware of the role differences. Except for the concept ENGLISH CANADIAN MALE, perceptions of the role-ethnic concepts fall into the familiar pattern of out-group perceptions being mediated largely by ethnic stereotypes and in-group perceptions being influenced more by role stereotypes. Evidence from both studies supports this pattern in $75 \%$ of the cases. None of the remaining cases actually run contrary to it; three of the cases show equal cue dominance probably because of the similarity in ratings of the two composing concepts. 
The correlational analyses suggest an important difference between the contact and no-contact groups' perceptions. The contact sample's awareness of role similarity (despite ethnic differences) between ENGLISH and FRENCH CANADIAN MALES, and between ENGLISH and FRENCH CANADIAN FEMALES, as demonstrated by their highly correlated $\underline{t}$ values, did not turn up in the multiple regression analysis. Even though both groups predominantly utilized the ethnic cue when considering French Canadians, the common-role correlations indicate that the contact group are using role information more than the no-contact group in these cases.

These findings bear directly on an hypothesis put forth by Malpass and Kravitz (1969) suggesting that differential experience with persons of another race leads to differential acquisition of cue utilization habits. If discriminations among persons of a certain group are frequently made, then within-group discriminative cue utilization habits will be formed, as was the case when our Ss rated their own group; but if contrasts of persons from the other group with one's own group are typically the case, then between-group cue utilization habits will be formed.

These results suggest that the amount of contact between the two ethnic groups is a very important factor in determining whether role or ethnic stereotypes will predominate in person perception. And there is evidence that not only amount of contact, but type of contact is a factor here. As well as having vicarious contact with French Canadians, the contact group was found to have slightly more experience with French Canadians, but it was mostly of an encounter nature. This extra contact was enough to show up a difference in the stereotype analysis of the two groups but not enough to make a difference in the beta weight_analysis. We would expect that with a greater amount of contact of either formal or informal nature with people from another 
ethnic group, the importance of ethnic information would decrease and instead role cues would be used. Further research along this line should include people having more formal and informal contact with another ethnic group to clarify this tentative conclusion.

\section{Implications}

The results of the present investigation have important implications for ethnic group relations. Earlier it was suggested that the use of role stereotypes will probably lead to a more accurate prediction of another person's behavior than a reliance on ethnic stereotypes. This conclusion was based on the theory that role stereotypes are essentially beliefs and expectations shared not only by the community, but also by the occupant of the role in question. Ethnic stereotypes, on the other hand, are expectations which are shared by one group with respect to members of another, but where a member of the ethnic group feels no obligation to conform to these expectations. In the present experiment, in-group perception was characterized by the use of role stereotypes. Our theory would indicate that this strategy should result in relatively accurate interaction. In light of the fact that we must regularly interact with members of our own ethnic group and have therefore adopted the strategy which leads to the most efficient interaction, the results tie in logically with the theory. For out-group perception, however, the results show a greater reliance on ethnic stereotypes which could lead to less efficent interaction in cross-cultural settings.

The negative aspect of these implications is offset, however, by the finding that contact with an ethnic group results in less reliance on ethnic cues and a corresponding increase in the use of role stereotypes. For the present study, contact with French Canadians was rather minimal, however, and 
it will be essential to determine whether closer contact with another ethnic group further enhances the use of role stereotypes in the process of person perception. 


\section{REFERENCES}

Amir, Y. Contact hypothesis in ethnic relations. Psychological Bulletin, $1969, \underline{71}, 319-342$.

Anderson, N. H., \& Jacobson, A. Effect of stimulus inconsistency and discounting instructions in personality impression formation. Journal of Personality and Social Psychology, 1965, 2, 531-539.

Asch, S. E. Forming impressions of personality. Journal of Abnormal and Social Psychology, 1946, 41, 258-290.

Brown, R. Social Psychology. New York: The Free Press, 1965.

Bruner, J. S., Shapiro, D., \& Tagiuri, R. The meaning of traits in isolation and in combination. In R. Tagiuri \& L. Petrullo (Eds.), Person Perception and Interpersonal Behavior. Stanford: Stanford University Press, 1958.

Campbe11, D. T. Stereotypes and the perception of group differences. American Psychologist, 1967, 22, 817-829.

Fishman, J. A. An examination of the process and function of social stereotyping. Journal of Social Psychology, 1956, 43, 27-64. Friedman, C. J., \& Gladden, J. W. Objective measurement of social role concept via the semantic differential. Psychological Reports, 1964, 14, 239-247.

Gardner, R. C., Wonnacott, E. J., \& Taylor, D. M. Ethnic stereotypes: A factor analytic investigation. Canadian Journal of Psychology, 1968, $\underline{22}, 35-44$.

Gardner, R. C., \& Taylor, D. M. Ethnic stereotypes: Their effects on person perception. Canadian Journal of Psychology, 1968, 22, 267-276. Gilbert, G. M. Stereotype persistence and change among college students. Journal of Abnormal and Social Psychology, 1951, 46, 245-254. 
Jones, E. E., \& de Charms, R. The organizing function of interaction roles in person perception. Journal of Abnormal and Social Psychology, 1958, $57,155-164$.

Jones, E. E., \& Thibaut, J. W. Interaction goals as bases of inference in interpersonal perception. In R. Tagiuri \& L. Petrullo (Eds.), Person Perception and Interpersonal Behavior. Stanford: Stanford University Press, 1958.

Katz, D., \& Braly, K. W. Racial stereotypes of 100 college students. Journal of Abnormal and Social Psychology, 1933, 28, 280-290.

Katz, D., \& Braly, K. W. Racial prejudice and racial stereotypes. Journal of Abnormal and Social Psychology, 1935, 30, 175-193.

Lambert, W. E. A social psychology of bilingualism. Journal of Social Issues, $1967, \underline{23}, 91-109$.

Lambert, W. E., Hodgson, R. C., Gardner, R. C., \& Fillenbaum, S. Evaluational reactions to spoken languages. Journal of Abnormal and Social Psychology, 1960, 60, 44-51.

Lippmann, W. Public Opinion. New York: Harcourt, Brace, 1922.

Malpass, R. S., \& Kravitz, J. Recognition for faces of own and other race. Journal of Personality and Social Psychology, 1969, 13, 330-334.

Meenes, M. A comparison of racial stereotypes of 1935 and 1942 . Journal of Social Psychology, 1943, 17, 327-336.

Osgood, C. E., Suci, G. J., \& Tannenbaum, P. H. The Measurement of Meaning. Urbana, Illinois: University of Illinois Press, 1957.

Pool, I. Effects of cross national contact on national and international images. In H. C. Kelman, (Ed.) International Behavior. New York: Holt, Rinehart \& Winston, 1965.

Razran, G. Ethnic dislikes and stereotypes: A laboratory study. Journal of Abnormal and Social Psychology, 1950, 45, 7-27. 
Sarbin, T. R., \& Rosenberg, B. G. Contributions to role-taking theory IV. A method for obtaining a qualitative estimate of the self. Journal of Social Psychology, 1955, 42, 71-81.

Sarbin, T. R., Taft, R., \& Bailey, D. E. Clinical inference and cognitive theory. New York: Holt, Rinehart \& Winston, 1960.

Secord, P. F. Facial features and inference processes in interpersonal perception. In R. Tagiuri and L. Petrullo (Eds.), Person Perception and Interpersonal Behavior. Stanford: Stanford University Press, 1958. Secord, P. F., Bevan, W., \& Katz, B. The Negro stereotype and perceptual accentuation. Journal of Abnormal and Social Psychology, 1956, 53, 78-83.

Secord, P. F. Stereotyping and favorableness in the perception of Negro faces. Journal of Abnormal and Social Psychology, 1959, 59, 309-315.

Tagiuri, R. Person perception. In G. Lindzey and E. Aronson (Eds.), Handbook of Social Psychology, Vol. 3. Toronto: Addison-Wesley, 1969. Tajfel, H., Sheikh, A. A., \& Gardner, R. C. Content of stereotypes and the inference of similarity between members of stereotyped groups. Acta Psychologia, 1964, 22, 191-201.

Taylor, D. M. , \& Gardner, R. C. Ethnic stereotypes: Their effects on the perception of communicators of varying credibility. Canadian Journal of Psychology, 1969, 23, 161-173.

Triandis, H. C., \& Fishbein, M. Cognitive interaction in person perception. Journal of Abnormal and Social Psychology, 1963, 64, 446-453.

Triandis, H. C., Loh, W. D., \& Levin, L. A. Race, status, quality of spoken English and opinions about civil rights as determinants of interpersonal attitudes. Journal of Personality and Social Psychology, 1966, $\underline{3}$, 468-472. 
Triandis, H. C., \& Vassiliou, V. Frequency of contact and stereotyping. Journal of Personality and Social Psychology, 1967, 7, 316-328.

Triandis, H. C., Vassiliou, V., \& Nassiakou, M. Three cross-cultural studies of subjective culture. Journal of Personality and Social Psychology, Monograph supplement, 1968, $8,4$.

Tucker, G. R. Judging personality from language usage: A Filipino example. Philippine Sociological Review, 1968, 16, 30-39.

Wishner, J. Reanalysis of "impressions of personality". Psychological Review, $1960, \underline{67}, 96-112$. 
TABLE 1

Content and $t$ Values of Role and Ethnic Stereotypes for Single Labels

I. English Canadian Ss

\begin{tabular}{|c|c|c|c|}
\hline STUDENT & TEACHER & ENGLISH CANADIAN & FRENCH CANADIAN \\
\hline likeable 38.43 & educated & likeable & proud \\
\hline ambitious & creative & competent $\quad 32.34$ & emotional 23.87 \\
\hline proud 29.24 & humane 26.49 & proud 32.33 & dissenting 23.30 \\
\hline competent 28.87 & demanding 25.36 & ambitious & demanding $\quad 22.19$ \\
\hline creative 28.64 & honest 25.06 & creative 30.50 & authoritarian 22.13 \\
\hline educated 27.67 & generous 24.61 & generous 29.22 & creative 21.56 \\
\hline demanding & sincere 24.49 & hard-working 27.94 & competent 21.39 \\
\hline materialistic 25.96 & likeable 24.07 & dominant 26.89 & likeable 21.34 \\
\hline dynamic 24.50 & competent 23.70 & studious 26.17 & dissatisfied 20.97 \\
\hline humane 24.16 & hard-working 23.46 & humane 25.93 & materialistic \\
\hline II. French Canadian & Ss & & \\
\hline STUDENT & TEACHER & ENGLISH CANADIAN & FRENCH CANADIAN \\
\hline bold 34.19 & educated 36.69 & educated 37.93 & proud 34.00 \\
\hline dynamic 31.02 & competent 35.43 & dominant $\quad 37.32$ & humane 33.98 \\
\hline educated 29.90 & honest 32.44 & ambitious 34.25 & materialistic 33.98 \\
\hline generous 29.20 & ambitious 32.33 & authoritarian 29.85 & studious 33.82 \\
\hline likeable 28.70 & dominant $\quad 31.21$ & studious 29.25 & educated 33.72 \\
\hline proud 27.64 & dynamic $\quad 30.90$ & sincere 28.04 & honest 30.86 \\
\hline ambitious 26.96 & proud 30.42 & dynamic $\quad 27.15$ & competent $\quad 30.29$ \\
\hline creative 26.88 & emotional 30.38 & emotional 26.53 & dissenting $\quad 30.13$ \\
\hline humane $\quad 25.97$ & demanding 29.07 & demanding 26.13 & bold 29.21 \\
\hline dissatisfied 25.94 & bold 28.28 & bold 25.68 & dynamic $\quad 27.74$ \\
\hline
\end{tabular}




\section{TABLE 2}

Content and $\underline{t}$ Values of Role-Ethnic Combination. Stereotypes

I. English Canadian Ss

\section{ENGLISH CANADIAN} STUDENT

ambitious 34.88

educated 33.01

likeable 29.38

proud 32.24

hard-working 29.38

sincere 28.30

generous 26.69

honest 26.69

competent 26.11

demanding 25.54
FRENCH CANADIAN

STUDENT

emotional 31.27

demanding 24.76

bold 22.81

dominant 22.31

creative 22.11

competent 22.02

humane 21.88

proud 21.83

studious 21.74

generous 21.27
ENGLISH CANADIAN
TEACHER

educated 35.14

ambitious $\quad 32.79$

competent 31.02

proud 30.31

generous 29.99

likeable 29.36

hard-working 27.48

studious 26.61

demanding $\quad 25.79$

humane 25.07
FRENCH CANADIAN TEACHER

educated 31.86

proud 28.50

ambitious 26.30

generous 26.17

humane 26.07

competent 25.74

studious 24.71

sincere 24.54

likeable 21.61

honest 21.59

II. French Canadian Ss

ENGLISH CANADIAN STUDENT

educated 50.08

competent 36.10

creative 33.17

dynamic $\quad 33.11$

studious 33.08

bold 32.03

demanding 29.66

honest 29.62

ambitious 29.15

proud 27.70

\begin{tabular}{l} 
FRENCH CANADIAN \\
STUDENT \\
\hline
\end{tabular}

proud 38.93

dynamic 35.57

educated $\quad 35.29$

bold 33.45

competent 33.38

sincere $\quad 32.38$

generous 32.27

dominant 31.58

superficial $\quad 30.71$

studious 30.41
ENGLISH CANADIAN TEACHER

ambitious 39.33

educated 38.04

dynamic $\quad 36.32$

studious 34.64

bold 32.52

proud 30.91

hard-working $\quad 30.59$

dominant 30.06

creative 29.96

sincere 29.92
FRENCH CANADIAN TEACHER

bold 42.04

hard-working $\quad 39.81$

competent $\quad 37.50$

educated 35.34

sincere $\quad 34.88$

likeable $\quad 34.84$

dynamic $\quad 34.28$

ambitious 33.33

honest 33.30

proud 32.33 
TABLE 3

Multiple Regression Beta Weight Analysis

on 30 Adjective Scales ${ }^{1}$

\begin{tabular}{cccc}
$\begin{array}{c}\text { English } \\
\text { Canadian }\end{array}$ & $\begin{array}{c}\text { French } \\
\text { Canadian }\end{array}$ & $\begin{array}{c}\text { English } \\
\text { Canadian }\end{array}$ & $\begin{array}{c}\text { French } \\
\text { Canadian }\end{array}$ \\
Student & Student & Teacher & Teacher \\
\hline
\end{tabular}

Barraute $\underline{S}$

No. of adjective scales with Role Cue dominant

No. of adjective scales with Ethnic Cue dominant

Smith's Falls Ss

No. of adjective scales with Role Cue dominant

No. of adjective scales with Ethnic Cue dominant

$1_{\text {Where the number of scales does not add up to } 30 \text {, the remainder are scales }}$ which displayed equal role and ethnic weights. 
TABLE 4

Content and $\underline{t}$ Values of Role and Ethnic Stereotypes for Single Labels I. Contact Group

MALE

Strong 44.31

dominant 40.02

intelligent 39.15

competitive 30.91

egotistic 28.55

sociable 28.40

artistic 27.52

stable 27.51

sincere 27.40

reserved 27.35
FEMALE

sociable 25.75

talkative 25.71

intelligent 24.7

sensitive 23.82

artistic $\quad 22.94$

impulsive 22.21

dynamic 21.57

colorful 21.56

proud 21.44

delicate 21.29
ENGLISH CANADIAN

logical 37.36

intelligent 35.72

proud 35.60

egotistic 34.65

strong $\quad 30.10$

stable 29.21

dominant 28.98

competitive 27.89

affectionate 27.68

traditional 27.00
FRENCH CANADIAN

affectionate $\quad 39.58$

talkative 38.08

emotional 34.21

artistic $\quad 34.04$

proud 33.01

colorful 31.00

strong $\quad 30.55$

sensitive 29.14

competitive 27.81

sociable 27.06

II. No-Contact Group

MALE

tenacious 36.08

competitive 34.63

intelligent $\quad 33.76$

strong $\quad 31.12$

egotistic 29.55

dominant 28.45

dynamic $\quad 27.41$

logical 27.40

artistic 25.82

stable 25.05
FEMALE

sociable 34.46

sensitive $\quad 31.70$

emotional 31.58

religious 27.56

proud 27.50

affectionate $\quad 26.19$

passive 26.05

traditional 25.33

competitive 24.51

egotistic 24.06
ENGLISH CANADIAN intelligent 36.44

artistic $\quad 35.79$

dominant 34.50

logical 33.61

dynamic 32.08

competitive 31.42

strong $\quad 30.19$

sociable 29.03

tenacious 28.15

stable 25.30
FRENCH CANADIAN

sensitive 38.82

affectionate $\quad 36.82$

colorful 33.25

artistic 33.20

impulsive 30.83

proud 30.46

talkative $\quad 30.36$

religious 29.75

emotional 29.31

egotistic 28.37 
TABLE 5

Content and $\underline{t}$ values of Role-Ethnic Combination Stereotypes

I. Contact Group

ENGLISH CANADIAN MALE

strong $\quad 35.74$

competitive 35.20

dominant $\quad 35.10$

logical 33.60

sociable $\quad 32.67$

intelligent 31.24

proud 30.83

stable 28.91

egotistic 27.55

affectionate 27.13
FRENCH CANADIAN MALE

sociable 37.53

proud 31.91

affectionate 31.89

dynamic 31.76

talkative 31.64

strong 31.20

emotional 29.27

impulsive 27.42

intelligent 27.31

colorful 27.26
ENGLISH CANADIAN FEMALE

sociable $\quad 34.29$

artistic 31.90

talkative 31.41

sincere $31.38^{\circ}$

intelligent $\quad 30.39$

affectionate 30.20

beautiful 27.79

dynamic 27.30

impulsive 27.01

emotional 26.06
FRENCH CANADIAN FEMALE

affectionate $\quad 43.40$

sociable 38.26

artistic 32.17

talkative 32.09

sincere 32.04

colorful 28.51

beautiful 27.53

impulsive 26.35

proud 25.95

dynamic 25.65

II. No-Contact Group

ENGLISH CANADIAN MALE

logical 35.79

competitive 35.36

dominant 35.21

tenacious 32.44

proud 30.42

strong 30.37

intelligent 29.78

stable 28.79

talkative 26.15

egotistic 26.03
FRENCH CANADIAN MALE

emotional 44.60

colorful $\quad 37.86$

proud 37.65

artistic 36.03

impulsive 35.84

sociable $\quad 33.35$

affectionate 32.32

talkative 32.13

strong 27.88

dominant 27.66
ENGLISH CANADIAN FEMALE

proud 32.63

dominant 30.75

talkative $\quad 30.45$

sociable 28.47

emotional 28.32

tenacious 27.63

egotistic 26.96

beautiful 26.81

artistic 25.77

affectionate 25.01
FRENCH CANADIAN FEMALE

talkative 24.79

proud 24.55

affectionate 24.02

religious 23.75

emotional 22.92

artistic 22.85

sociable 22.32

traditional 21.90

sincere 21.67

colorful 21.54 
TABLE 6

Inter-Correlations Among $\underline{t}$ Values for

Role-Ethnic Combination Stimuli

Cormon Ethnicity

English Canadian Female -

English Canadian Male

French Canadian Female -

French Canadian Male

Contact Group

No-Contact Group

Common Role

English Canadian Male -

French Canadian Male

English Canadian Female -

French Canadian Female

\begin{tabular}{|cc|}
\hline Contact Group & No-Contact Group \\
\hline .159 & .227 \\
$.506^{* *}$ & $.582^{* *}$ \\
& \\
& \\
$.434^{*}$ & \\
& \\
$.740^{* *}$ & .018 \\
\end{tabular}

** Significant at .01 level.

* Significant at .05 level. 
TABLE 7

Multiple Regression Beta Weights Analysis

on 25 Adjective Scales ${ }^{1}$

Contact $\underline{S}$

\begin{tabular}{cccc}
$\begin{array}{c}\text { English } \\
\text { Canadian } \\
\text { Male }\end{array}$ & $\begin{array}{c}\text { French } \\
\text { Canadian } \\
\text { Male }\end{array}$ & $\begin{array}{c}\text { English } \\
\text { Canadian } \\
\text { Female }\end{array}$ & $\begin{array}{c}\text { French } \\
\text { Canadian } \\
\text { Female }\end{array}$ \\
\hline
\end{tabular}

No. of adjective scales

with Role Cue dominant

12

4

15

9

No. of adjective scales

with Ethnic Cue dominant

13

20

8

16

No-Contact $\underline{S} \mathbf{s}$

No. of adjective scales

with Role Cue dominant

12

4

16

8

No. of adjective scales

with Ethnic Cue dominant

11

21

8

16

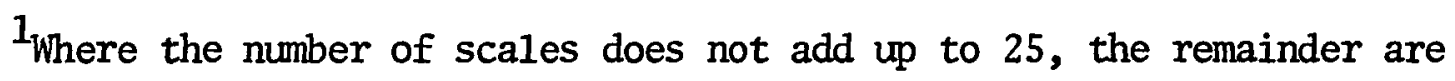
scales which displayed equal role and ethnic weights. 
APPENDIX 1

List of Traits used by English Canadian and French Canadian Ss to rate Concepts in Experiment 1

$\begin{array}{ll}\text { ambitious - ambitieux } & \text { hard-working - travailleur } \\ \text { authoritarian - authoritaire } & \text { honest - honnête } \\ \text { bold - audacieux } & \text { humane - humain } \\ \text { cold - froid } & \text { insecure - insécure } \\ \text { competent - compétent } & \text { likeable - sympathique } \\ \text { creative - innovateur } & \text { materialistic - matérialiste } \\ \text { demanding - exigeant } & \text { open-minded - ouvert } \\ \text { dissatisfied - insatisfait } & \text { oppressed - brimé } \\ \text { dissenting - contestataire } & \text { patriotic - patriote } \\ \text { dominant - dominateur } & \text { proud - fier } \\ \text { dynamic - dynamique } & \text { sincere - sincère } \\ \text { educated - instruit } & \text { studious - studieux } \\ \text { egotistic - égotiste } & \text { superficial - superficiel } \\ \text { emotional - émotif } & \text { traditional - traditionaliste } \\ \text { generous - généreux } & \text { unintelligent - borné }\end{array}$


Behavior Dimensions used by English Canadian and French Canadian S to rate Role and Ethnic-Role Concepts in Experiment 1

\section{STUDENT Behaviors}

1. A student will always get support from another student. Un étudiant trouve toujours un allie dans un autre étudiant.

2. A student is regarded as a number rather than as an individual by his teachers.

L'étudiant est considéré corme un numéro-matricule par ses professeurs.

3. Teachers expect that students will swallow everything they tell them. Les professeurs $s^{\prime}$ attendent à ce que les étudiants gobent tout ce qu'ils disent.

4. It is easy for a student to discuss things with a teacher. II est facile pour un étudiant de dialoguer avec un professeur.

5. Students feel that they must challenge authority. Les étudiants se voient dans 1'obligation de contester les authorités.

\section{TEACHER Behaviors}

1. Teachers show favoritism towards students they prefer. Les professeurs font preuve de favoritisme envers leurs étudiants préférés.

2. Teachers are afraid of the authorities. Les professeurs ont peur des autorités.

3. Teachers are understanding in regard to the problems of their students. Les professeurs font preuve de compréhension vis-à-vis les difficultés de leur élèves.

4. Teachers are dedicated to their students. Les professeurs se dévouent beaucoup pour les étudiants.

5. Teachers think it important to have a good relationship with their students. Les professeurs jugent important $d$ 'avoir de bonnes relations aves les étudiants. 
APPENDIX 2

I. French Canadian Ss' Standardized Beta Weights for the Ethnic and role Cue of the four Combination Concepts in Experiment 1.

\begin{tabular}{|c|c|c|c|c|c|c|c|c|}
\hline & E.C. & $\begin{array}{l}\text { Stu- } \\
\text { dent }\end{array}$ & F.C. & $\begin{array}{l}\text { Stu- } \\
\text { dent }\end{array}$ & E.C. & $\begin{array}{l}\text { Tea- } \\
\text { cher }\end{array}$ & F.C. & $\begin{array}{l}\text { Tea- } \\
\text { cher }\end{array}$ \\
\hline $\begin{array}{l}\text { ambitious } \\
\text { authoritarian } \\
\text { bold } \\
\text { competent } \\
\text { creative }\end{array}$ & $\begin{array}{l}.47 \\
.61 \\
.26 \\
.15 \\
.41\end{array}$ & $\begin{array}{r}.15 \\
-.13 \\
-.02 \\
.03 \\
-.04\end{array}$ & $\begin{array}{r}-.02 \\
.31 \\
.07 \\
.27 \\
.26\end{array}$ & $\begin{array}{l}.47 \\
.45 \\
.19 \\
.52 \\
.46\end{array}$ & $\begin{array}{r}.39 \\
.22 \\
-.02 \\
.21 \\
.57\end{array}$ & $\begin{array}{r}.36 \\
-.03 \\
.13 \\
.05 \\
-.05\end{array}$ & $\begin{array}{r}-.10 \\
.19 \\
.21 \\
.03 \\
.28\end{array}$ & $\begin{array}{l}.54 \\
.47 \\
.21 \\
.70 \\
.56\end{array}$ \\
\hline $\begin{array}{l}\text { demanding } \\
\text { dissatisfied } \\
\text { dissenting } \\
\text { dominant } \\
\text { dynamic }\end{array}$ & $\begin{array}{l}.26 \\
.12 \\
.42 \\
.67 \\
.58\end{array}$ & $\begin{array}{r}-.06 \\
.024 \\
-.08 \\
.04 \\
-.01\end{array}$ & $\begin{array}{l}.15 \\
.52 \\
.05 \\
.31 \\
.36\end{array}$ & $\begin{array}{l}.70 \\
.45 \\
.57 \\
.19 \\
.21\end{array}$ & $\begin{array}{l}.16 \\
.35 \\
.18 \\
.36 \\
.65\end{array}$ & $\begin{array}{l}.37 \\
.46 \\
.37 \\
.05 \\
.01\end{array}$ & $\begin{array}{r}.12 \\
.28 \\
-.18 \\
.02 \\
.33\end{array}$ & $\begin{array}{l}.26 \\
.27 \\
.60 \\
.33 \\
.16\end{array}$ \\
\hline $\begin{array}{l}\text { educated } \\
\text { egotistic } \\
\text { emotional } \\
\text { generous } \\
\text { hard-working }\end{array}$ & $\begin{array}{l}.11 \\
.36 \\
.39 \\
.44 \\
.40\end{array}$ & $\begin{array}{l}.37 \\
.13 \\
.01 \\
.08 \\
.04\end{array}$ & $\begin{array}{l}.04 \\
.20 \\
.23 \\
.14 \\
.11\end{array}$ & $\begin{array}{l}.64 \\
.60 \\
.40 \\
.54 \\
.45\end{array}$ & $\begin{array}{l}.29 \\
.39 \\
.28 \\
.59 \\
.39\end{array}$ & $\begin{array}{r}.29 \\
.17 \\
.19 \\
-.14 \\
-.05\end{array}$ & $\begin{array}{r}.15 \\
-.04 \\
-.30 \\
-.09 \\
.18\end{array}$ & $\begin{array}{l}.44 \\
.59 \\
.49 \\
.46 \\
.33\end{array}$ \\
\hline $\begin{array}{l}\text { honest } \\
\text { humane } \\
\text { insecure } \\
\text { likeable } \\
\text { materialistic }\end{array}$ & $\begin{array}{l}.53 \\
.51 \\
.16 \\
.58 \\
.28\end{array}$ & $\begin{array}{l}-.002 \\
.23 \\
.14 \\
.06 \\
.21\end{array}$ & $\begin{array}{l}.46 \\
.24 \\
.28 \\
.15 \\
.18\end{array}$ & $\begin{array}{r}-.01 \\
.48 \\
.30 \\
.47 \\
.52\end{array}$ & $\begin{array}{l}.45 \\
.45 \\
.27 \\
.48 \\
.34\end{array}$ & $\begin{array}{l}.05 \\
.22 \\
.41 \\
.23 \\
.25\end{array}$ & $\begin{array}{l}.18 \\
.19 \\
.28 \\
.20 \\
.29\end{array}$ & $\begin{array}{l}.33 \\
.67 \\
.42 \\
.47 \\
.30\end{array}$ \\
\hline $\begin{array}{l}\text { open-minded } \\
\text { oppressed } \\
\text { patriotic } \\
\text { proud } \\
\text { sincere }\end{array}$ & $\begin{array}{l}.46 \\
.47 \\
.25 \\
.50 \\
.46\end{array}$ & $\begin{array}{l}.28 \\
.31 \\
.24 \\
.15 \\
.22\end{array}$ & $\begin{array}{r}.42 \\
-.03 \\
.01 \\
.26 \\
.31\end{array}$ & $\begin{array}{l}.40 \\
.38 \\
.51 \\
.38 \\
.08\end{array}$ & $\begin{array}{l}.07 \\
.31 \\
.24 \\
.31 \\
.55\end{array}$ & $\begin{array}{l}.08 \\
.25 \\
.53 \\
.42 \\
.11\end{array}$ & $\begin{array}{l}.28 \\
.19 \\
.11 \\
.10 \\
.12\end{array}$ & $\begin{array}{l}.25 \\
.59 \\
.38 \\
.28 \\
.55\end{array}$ \\
\hline $\begin{array}{l}\text { studious } \\
\text { superficial } \\
\text { traditional } \\
\text { umintelligent }\end{array}$ & $\begin{array}{l}.46 \\
.40 \\
.58 \\
.62\end{array}$ & $\begin{array}{l}.12 \\
.06 \\
.19 \\
.10\end{array}$ & $\begin{array}{l}.01 \\
.21 \\
.35 \\
.39\end{array}$ & $\begin{array}{l}.66 \\
.06 \\
.49 \\
.14\end{array}$ & $\begin{array}{l}.33 \\
.00 \\
.36 \\
.24\end{array}$ & $\begin{array}{l}.18 \\
.18 \\
.41 \\
.34\end{array}$ & $\begin{array}{l}.20 \\
.04 \\
.46 \\
.06\end{array}$ & $\begin{array}{l}.21 \\
.45 \\
.62 \\
.53\end{array}$ \\
\hline
\end{tabular}

Due to a misprint in the questionnaire, the adjective scale "cold" had to be eliminated from this analysis. 
II. English Canadian Ss' Standardized Beta Weights for the Ethnic and Role Cue of the four Combination Concepts in Experiment 1.

\begin{tabular}{|c|c|c|c|c|c|c|c|c|}
\hline & E.C. & $\begin{array}{l}\text { Stu- } \\
\text { dent }\end{array}$ & F.C. & $\begin{array}{l}\text { Stu- } \\
\text { dent }\end{array}$ & E.C. & $\begin{array}{l}\text { Tea- } \\
\text { cher }\end{array}$ & F.C. & $\begin{array}{l}\text { Tea- } \\
\text { cher }\end{array}$ \\
\hline $\begin{array}{l}\text { ambitious } \\
\text { authoritarian } \\
\text { bold } \\
\text { cold } \\
\text { competent }\end{array}$ & $\begin{array}{l}.29 \\
.33 \\
.23 \\
.38 \\
.17\end{array}$ & $\begin{array}{l}.53 \\
.23 \\
.41 \\
.10 \\
.39\end{array}$ & $\begin{array}{l}.57 \\
.35 \\
.54 \\
.41 \\
.55\end{array}$ & $\begin{array}{r}.07 \\
.05 \\
-.01 \\
-.18 \\
.16\end{array}$ & $\begin{array}{l}.16 \\
.13 \\
.36 \\
.27 \\
.21\end{array}$ & $\begin{array}{l}.67 \\
.50 \\
.25 \\
.15 \\
.57\end{array}$ & $\begin{array}{r}.24 \\
-.05 \\
.16 \\
.20 \\
.68\end{array}$ & $\begin{array}{l}.30 \\
.36 \\
.32 \\
.22 \\
.15\end{array}$ \\
\hline $\begin{array}{l}\text { creative } \\
\text { demanding } \\
\text { dissatisfied } \\
\text { dissenting } \\
\text { dominant }\end{array}$ & $\begin{array}{l}.32 \\
.46 \\
.32 \\
.22 \\
.31\end{array}$ & $\begin{array}{r}.51 \\
.28 \\
.06 \\
-.08 \\
.36\end{array}$ & $\begin{array}{l}.38 \\
.38 \\
.43 \\
.38 \\
.43\end{array}$ & $\begin{array}{r}.42 \\
.03 \\
.28 \\
-.09 \\
.15\end{array}$ & $\begin{array}{l}.27 \\
.21 \\
.47 \\
.31 \\
.07\end{array}$ & $\begin{array}{l}.50 \\
.46 \\
.27 \\
.40 \\
.46\end{array}$ & $\begin{array}{r}.29 \\
-.05 \\
.28 \\
.09 \\
.20\end{array}$ & $\begin{array}{l}.28 \\
.61 \\
.16 \\
.37 \\
.12\end{array}$ \\
\hline $\begin{array}{l}\text { dynamic } \\
\text { educated } \\
\text { egotistic } \\
\text { emotional } \\
\text { generous }\end{array}$ & $\begin{array}{l}.29 \\
.18 \\
.25 \\
.54 \\
.62\end{array}$ & $\begin{array}{l}.56 \\
.57 \\
.35 \\
.26 \\
.06\end{array}$ & $\begin{array}{l}.45 \\
.14 \\
.45 \\
.38 \\
.42\end{array}$ & $\begin{array}{l}.35 \\
.44 \\
.30 \\
.39 \\
.14\end{array}$ & $\begin{array}{l}.08 \\
.40 \\
.34 \\
.27 \\
.41\end{array}$ & $\begin{array}{l}.52 \\
.31 \\
.07 \\
.50 \\
.34\end{array}$ & $\begin{array}{l}.25 \\
.21 \\
.45 \\
.22 \\
.19\end{array}$ & $\begin{array}{r}.33 \\
.18 \\
-.10 \\
.40 \\
.36\end{array}$ \\
\hline $\begin{array}{l}\text { hard-working } \\
\text { honest } \\
\text { humane } \\
\text { insecure } \\
\text { likeable }\end{array}$ & $\begin{array}{l}.35 \\
.52 \\
.66 \\
.01 \\
.38\end{array}$ & $\begin{array}{l}.19 \\
.28 \\
.24 \\
.23 \\
.33\end{array}$ & $\begin{array}{l}.53 \\
.08 \\
.52 \\
.44 \\
.52\end{array}$ & $\begin{array}{l}.13 \\
.51 \\
.23 \\
.28 \\
.11\end{array}$ & $\begin{array}{l}.08 \\
.36 \\
.52 \\
.29 \\
.33\end{array}$ & $\begin{array}{l}.59 \\
.30 \\
.23 \\
.08 \\
.43\end{array}$ & $\begin{array}{l}.47 \\
.35 \\
.41 \\
.11 \\
.50\end{array}$ & $\begin{array}{l}.42 \\
.34 \\
.33 \\
.17 \\
.35\end{array}$ \\
\hline $\begin{array}{l}\text { materialistic } \\
\text { open-minded } \\
\text { oppressed } \\
\text { patriotic } \\
\text { proud }\end{array}$ & $\begin{array}{l}.19 \\
.40 \\
.39 \\
.31 \\
.58\end{array}$ & $\begin{array}{r}.24 \\
.35 \\
-.04 \\
.48 \\
.12\end{array}$ & $\begin{array}{l}.32 \\
.52 \\
.14 \\
.74 \\
.41\end{array}$ & $\begin{array}{r}.05 \\
.12 \\
.44 \\
.11 \\
-.16\end{array}$ & $\begin{array}{l}.38 \\
.22 \\
.26 \\
.18 \\
.35\end{array}$ & $\begin{array}{l}.38 \\
.49 \\
.37 \\
.62 \\
.17\end{array}$ & $\begin{array}{l}.37 \\
.52 \\
.32 \\
.65 \\
.59\end{array}$ & $\begin{array}{l}.15 \\
.18 \\
.50 \\
.06 \\
.00\end{array}$ \\
\hline $\begin{array}{l}\text { sincere } \\
\text { studious } \\
\text { superficial } \\
\text { traditional }\end{array}$ & $\begin{array}{l}.56 \\
.27 \\
.28 \\
.36\end{array}$ & $\begin{array}{l}.13 \\
.30 \\
.15 \\
.46\end{array}$ & $\begin{array}{l}.53 \\
.39 \\
.30 \\
.55\end{array}$ & $\begin{array}{l}.17 \\
.13 \\
.24 \\
.32\end{array}$ & $\begin{array}{l}.18 \\
.26 \\
.29 \\
.19\end{array}$ & $\begin{array}{l}.24 \\
.58 \\
.33 \\
.46\end{array}$ & $\begin{array}{l}.30 \\
.36 \\
.40 \\
.51\end{array}$ & $\begin{array}{l}.43 \\
.52 \\
.38 \\
.05\end{array}$ \\
\hline
\end{tabular}

Due to a misprint in the questionnaire, the adjective scale "unintelligent" had to be eliminated from this analysis. 


\section{APPENDIX 3}

List of Traits used by Contact and No-Contact $\underline{\text { Ss }}$ to rate Concepts in Experiment 2

$\begin{array}{ll}\text { affectionate } & \text { passive } \\ \text { artistic } & \text { proud } \\ \text { beautiful } & \text { religious } \\ \text { colorful } & \text { reserved } \\ \text { competitive } & \text { sensitive } \\ \text { delicate } & \text { sincere } \\ \text { dominant } & \text { sociable } \\ \text { dynamic } & \text { stable } \\ \text { egotistic } & \text { strong } \\ \text { emotional } & \text { talkative } \\ \text { impulsive } & \text { tenacious } \\ \text { intelligent } & \text { traditional } \\ \text { logical } & \end{array}$




\section{APPENDIX 4}

I. Contact Group's Standardized Beta Weights for the Ethnic and Role Cue of the four Combination Concepts in Experiment 2.

\begin{tabular}{|c|c|c|c|c|c|c|c|c|}
\hline $\begin{array}{l}\text { affectionate } \\
\text { artistic } \\
\text { beautiful } \\
\text { colorful } \\
\text { competitive }\end{array}$ & $\begin{array}{l}.48 \\
.50 \\
.14 \\
.53 \\
.49\end{array}$ & $\begin{array}{l}.03 \\
.25 \\
.55 \\
.30 \\
.59\end{array}$ & $\begin{array}{l}.29 \\
.43 \\
.13 \\
.42 \\
.39\end{array}$ & $\begin{array}{l}.42 \\
.23 \\
.80 \\
.30 \\
.22\end{array}$ & $\begin{array}{l}.22 \\
.12 \\
.26 \\
.64 \\
.31\end{array}$ & $\begin{array}{r}.59 \\
.39 \\
.39 \\
-.03 \\
.30\end{array}$ & $\begin{array}{l}.06 \\
.38 \\
.20 \\
.59 \\
.09\end{array}$ & $\begin{array}{l}.22 \\
.09 \\
.31 \\
.24 \\
.02\end{array}$ \\
\hline $\begin{array}{l}\text { delicate } \\
\text { dominant } \\
\text { dynamic } \\
\text { egotistic } \\
\text { emotional }\end{array}$ & $\begin{array}{l}.68 \\
.41 \\
.25 \\
.21 \\
.30\end{array}$ & $\begin{array}{l}.15 \\
.38 \\
.40 \\
.35 \\
.39\end{array}$ & $\begin{array}{l}.19 \\
.27 \\
.35 \\
.81 \\
.79\end{array}$ & $\begin{array}{r}.42 \\
-.04 \\
.49 \\
-.03 \\
.14\end{array}$ & $\begin{array}{r}-.20 \\
.06 \\
.24 \\
.00 \\
-.02\end{array}$ & $\begin{array}{r}.44 \\
.31 \\
-.01 \\
.01 \\
.59\end{array}$ & $\begin{array}{r}-.03 \\
-.02 \\
-.10 \\
.55 \\
.41\end{array}$ & $\begin{array}{l}.27 \\
.24 \\
.32 \\
.44 \\
.07\end{array}$ \\
\hline $\begin{array}{l}\text { impulsive } \\
\text { intelligent } \\
\text { logical } \\
\text { passive } \\
\text { proud }\end{array}$ & $\begin{array}{r}-.02 \\
.09 \\
.54 \\
.30 \\
.33\end{array}$ & $\begin{array}{l}.51 \\
.62 \\
.32 \\
.40 \\
.36\end{array}$ & $\begin{array}{l}.73 \\
.45 \\
.64 \\
.67 \\
.40\end{array}$ & $\begin{array}{l}.13 \\
.07 \\
.02 \\
.04 \\
.34\end{array}$ & $\begin{array}{r}.06 \\
-.05 \\
.10 \\
.04 \\
.42\end{array}$ & $\begin{array}{r}.31 \\
.41 \\
.81 \\
-.13 \\
.20\end{array}$ & $\begin{array}{l}.54 \\
.08 \\
.35 \\
.28 \\
.27\end{array}$ & $\begin{array}{r}.30 \\
-.06 \\
.57 \\
.11 \\
-.05\end{array}$ \\
\hline $\begin{array}{l}\text { religious } \\
\text { reserved } \\
\text { sensitive } \\
\text { sincere } \\
\text { sociable }\end{array}$ & $\begin{array}{r}.23 \\
-.07 \\
.39 \\
.69 \\
.44\end{array}$ & $\begin{array}{r}.32 \\
.23 \\
.32 \\
-.18 \\
.26\end{array}$ & $\begin{array}{l}.67 \\
.19 \\
.58 \\
.69 \\
.56\end{array}$ & $\begin{array}{l}.45 \\
.19 \\
.17 \\
.13 \\
.23\end{array}$ & $\begin{array}{r}.42 \\
.17 \\
-.03 \\
. .26 \\
-.01\end{array}$ & $\begin{array}{r}.38 \\
-.06 \\
.71 \\
.55 \\
.33\end{array}$ & $\begin{array}{l}.76 \\
.34 \\
.58 \\
.15 \\
.65\end{array}$ & $\begin{array}{r}.13 \\
-.19 \\
.16 \\
.29 \\
.27\end{array}$ \\
\hline $\begin{array}{l}\text { stable } \\
\text { strong } \\
\text { talkative } \\
\text { tenacious } \\
\text { traditional }\end{array}$ & $\begin{array}{l}.17 \\
.49 \\
.15 \\
.56 \\
.27\end{array}$ & $\begin{array}{l}.30 \\
.15 \\
.11 \\
.39 \\
.20\end{array}$ & $\begin{array}{l}.46 \\
.35 \\
.58 \\
.40 \\
.74\end{array}$ & $\begin{array}{r}-.26 \\
.03 \\
.46 \\
.27 \\
.21\end{array}$ & $\begin{array}{l}.04 \\
.23 \\
.02 \\
.52 \\
.28\end{array}$ & $\begin{array}{l}.24 \\
.18 \\
.07 \\
.39 \\
.31\end{array}$ & $\begin{array}{l}.46 \\
.24 \\
.37 \\
.19 \\
.43\end{array}$ & $\begin{array}{r}.10 \\
.44 \\
.22 \\
.23 \\
-.08\end{array}$ \\
\hline
\end{tabular}


II. No-Contact Group's Standardized Beta Weights for the Ethnic and Role Cue of the four combination Concepts in Experiment 2.

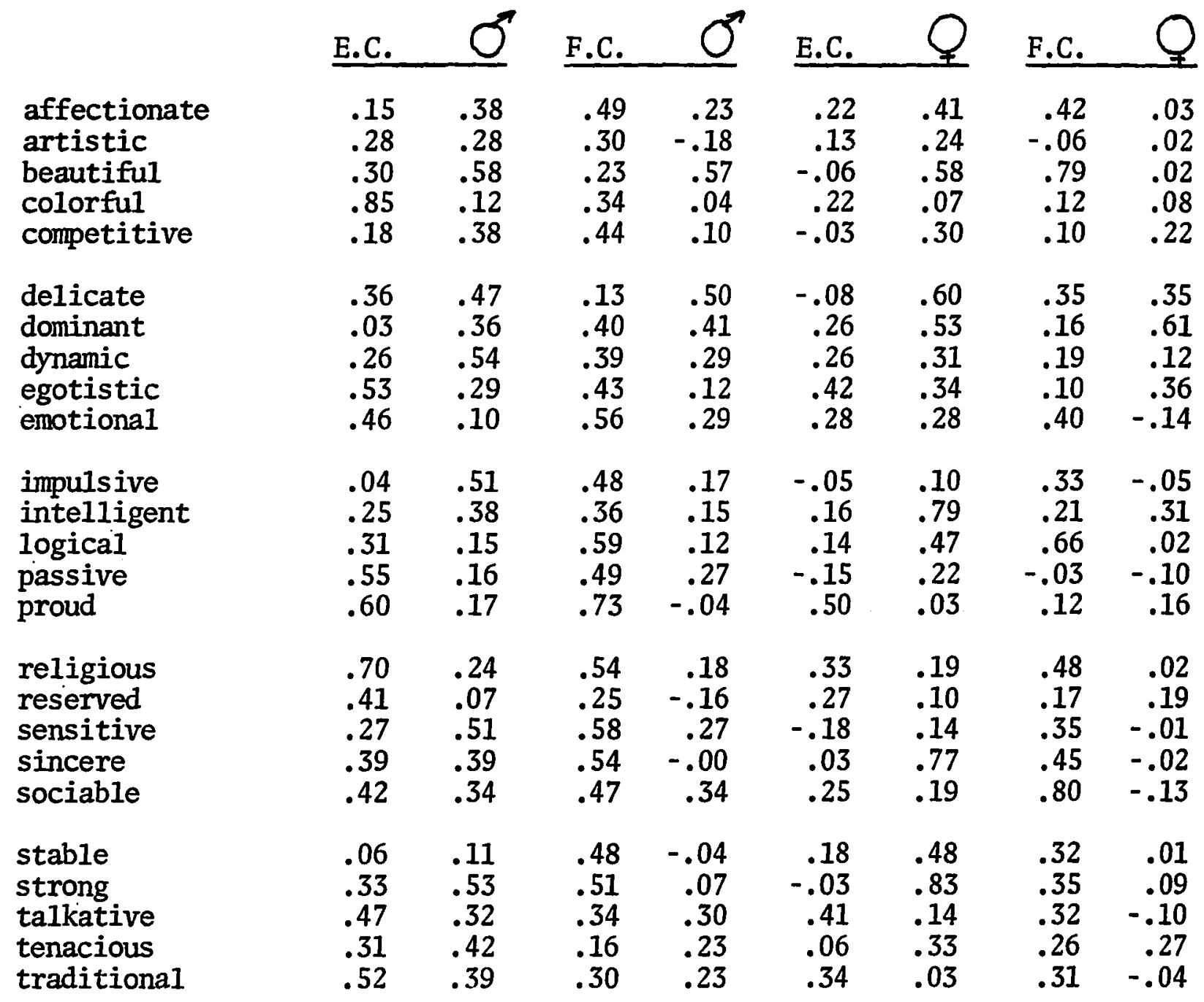

